\title{
Fiscal Devaluations
}

\section{Citation}

Farhi, Emmanuel, Gita Gopinath, and Oleg Itskhoki. 2014. Fiscal Devaluations. The Review of Economic Studies 81, no. 2: 725-760.

\section{Published Version}

doi:10.1093/restud/rdt036

\section{Permanent link}

http://nrs.harvard.edu/urn-3:HUL.InstRepos:12336336

\section{Terms of Use}

This article was downloaded from Harvard University's DASH repository, and is made available under the terms and conditions applicable to Open Access Policy Articles, as set forth at http:// nrs.harvard.edu/urn-3:HUL.InstRepos:dash.current.terms-of-use\#OAP

\section{Share Your Story}

The Harvard community has made this article openly available.

Please share how this access benefits you. Submit a story.

Accessibility 


\title{
Fiscal Devaluations*
}

\author{
Emmanuel Farhi \\ Gita Gopinath \\ Harvard University \\ Harvard University \\ Oleg Itskhoki \\ Princeton University
}

First Draft: June 3, 2011

This Draft: August 29, 2013

\begin{abstract}
We show that even when the exchange rate cannot be devalued, a small set of conventional fiscal instruments can robustly replicate the real allocations attained under a nominal exchange rate devaluation in a dynamic New Keynesian open economy environment. We perform the analysis under alternative pricing assumptions - producer or local currency pricing, along with nominal wage stickiness; under arbitrary degrees of asset market completeness and for general stochastic sequences of devaluations. There are two types of fiscal policies equivalent to an exchange rate devaluation-one, a uniform increase in import tariff and export subsidy, and two, a value-added tax increase and a uniform payroll tax reduction. When the devaluations are anticipated, these policies need to be supplemented with a consumption tax reduction and an income tax increase. These policies are revenue neutral. In certain cases equivalence requires, in addition, a partial default on foreign bond holders. We discuss the issues of implementation of these policies, in particular, under the circumstances of a currency union.
\end{abstract}

${ }^{*}$ We thank Andrew Abel, Philippe Aghion, Alberto Alesina, Pol Antràs, Mark Aguiar, Gianluca Benigno, Raj Chetty, Arnaud Costinot, Michael Devereux, Charles Engel, Francesco Franco, Xavier Gabaix, Etienne Gagnon, Fabio Ghironi, Elhanan Helpman, Olivier Jeanne, Urban Jermann, Mike Golosov, João Gomes, Gene Grossman, John Leahy, Elias Papaioannou, Veronica Rappoport, Ricardo Reis, Richard Rogerson, Martín Uribe, Adrien Verdelhan, Michael Woodford and seminar/conference participants at NES-HSE, ECB, Frankfurt, Princeton, Federal Reserve Board, Columbia, NBER IFM, Wharton, NYU, Harvard, MIT, NY Fed, LSE for their comments, and Eduard Talamas for excellent research assistance. 


\section{Introduction}

Exchange rate devaluations have long been proposed as a desirable policy response to macroeconomic shocks that impair a country's competitiveness in the presence of price and wage rigidities. Milton Friedman famously argued for flexible exchange rates on these grounds. Yet countries that wish to or have to maintain a fixed exchange rate cannot resort to exchange rate devaluations. In this paper we show how a country can use unilateral fiscal policy to generate the same real outcomes as those following a nominal exchange rate devaluation, while keeping the nominal exchange rate fixed.

This question about fiscal devaluations dates back to the period of the gold standard when countries could not devalue their currencies. At that time, Keynes (1931) had proposed that a uniform ad valorem tariff on all imports plus a uniform subsidy on all exports would have the same impact as an exchange rate devaluation. Recently, it has also been conjectured that a similar outcome could be achieved by increasing value-added taxes and cutting payroll taxes (e.g., social security contributions).

The current crisis in the Euro area has brought fiscal devaluations to the forefront of policy. The Euro has been blamed for the inability of countries like Greece, Portugal, Spain, Italy and even France to devalue their exchange rates and restore their competitiveness in international markets. ${ }^{1}$ Faced with the dramatic alternatives of austerity-ridden internal devaluation and exit from the Euro, countries in the Eurozone are considering the option of fiscal devaluations. Indeed, in 2012, France has implemented a fiscal devaluation. Previous examples include Denmark in 1988, Sweden in 1993, and Germany in 2006. Fiscal devaluations have clearly become a serious policy option.

Despite discussions in policy circles, there is little formal analysis of fiscal devaluations. ${ }^{2}$ This is an area where the policy debate is ahead of academic knowledge. This paper is intended to bridge this gap, by providing the first formal analysis of fiscal devaluations in a stochastic dynamic general equilibrium New Keynesian open economy environment. ${ }^{3}$ In doing so, we learn under what circumstances the tariff-cum-subsidy and VAT-cum-payroll fiscal interventions suffice to attain equivalence and when they need to be supplemented with additional policy adjustments.

\footnotetext{
${ }^{1}$ For popular policy writings on the topic see, for example, Feldstein in the Financial Times (February 17, 2010), Krugman in the New York Times (May 1, 2010), and Roubini in the Financial Times (June 13, 2011).

${ }^{2}$ For policy discussions, see for example Farhi and Werning (2007), Cavallo and Cottani (2010), IMF Press Release on Portugal (May 5, 2011), and IMF's September 2011 Fiscal Monitor.

${ }^{3}$ We adopt the New Keynesian framework with nominal rigidities as it provides the most natural laboratory for studying the real consequences of a nominal devaluation, however, our equivalence results between nominal and fiscal devaluations generalize beyond the models with nominal frictions.
} 
We define a fiscal devaluation of size $\delta_{t}$ at date $t$ to be a set of unilateral fiscal polices that implements the same real allocation as under a nominal exchange rate devaluation of size $\delta_{t}$, but holding the nominal exchange rate fixed. We explore a general path of $\delta_{t}$, including both expected and unexpected devaluations. Since the nature of price rigidity - whether prices are set in the currency of the producers or in local currency - is central for the real effects of nominal devaluations (see, for example, Lane, 2001; Corsetti, 2008), we allow for both the cases of producer (PCP) and local currency pricing (LCP) and for nominal wage rigidity. ${ }^{4}$ Additionally, we allow for a wide range of alternative international asset market structures, including complete markets, and various degrees of incompleteness such as international trade in risk-free nominal bonds only or international trade in equities.

We find that, first, despite the fact that the actual allocations induced by devaluations in New Keynesian environments are sensitive to the details of the environment, there exists a small set of fiscal instruments that can robustly replicate the effects - both on real variables and nominal prices - of nominal exchange rate devaluations across all specifications. The exact details of which instruments need to be used depend on the extent of completeness of asset markets, the currency denomination of bonds and the expected or unexpected nature of devaluations. Second, the required adjustment in taxes is only a function of $\delta_{t}$, the size of the required devaluation, and is independent of all details of the environment, such as for example the degree of wage and price stickiness, and the type of pricing (local or producer currency). Third, when all proposed tax instruments are used a fiscal devaluation is government revenue neutral. Otherwise, we show that these policies generate additional government revenue in periods of trade deficits.

We study both types of fiscal devaluations - a uniform increase in import tariffs and export subsidies and a uniform increase in value-added taxes and reduction in payroll taxes. The dynamic analysis reveals that both of these policies, in general, need to be accompanied by a uniform reduction in consumption taxes and an increase in income taxes. ${ }^{5}$ However, under some circumstances, changes in consumption and income taxes can be dispensed with. Whether this latter option is possible depends on the extent of completeness of asset markets and whether the exchange rate movements that are being mimicked are anticipated or unanticipated.

To provide intuition for the underlying mechanisms, consider the case of producer cur-

\footnotetext{
${ }^{4} \mathrm{PCP}$ refers to the case when prices are sticky in the currency of the producer (exporter), while LCP is the case when prices are sticky in the currency of the consumer (importer) of the good.

${ }^{5} \mathrm{~A}$ consumption tax is equivalent to a sales tax that is applied only to final goods, and not to intermediate goods. In our setup all goods are final, and hence consumption and sales taxes are always equivalent. Further, under the tariff-based policy, an increase in income tax should extend to both wage income and dividend income, while under the VAT-based policy, the dividend-income tax should be left unchanged.
} 
rency pricing $(\mathrm{PCP})$. One of the channels through which a nominal devaluation raises relative output at home is through a depreciation of home's terms of trade that makes home goods cheaper relative to foreign goods. This movement in the terms of trade can be mimicked either through a combination of import tariff and export subsidy or through an increase in the value-added tax (which is reimbursed to exporters and levied on importers). Additionally, to ensure that prices at home are the same as under a nominal devaluation, an increase in the value-added tax needs to be offset with a reduction in the payroll tax. The relative prices of all goods then respond identically under a fiscal and nominal devaluation.

When is a reduction in consumption taxes and an increase in income taxes required? Without a reduction in consumption taxes, fiscal devaluations result in an appreciated real exchange rate relative to a nominal devaluation. This is because fiscal devaluations, despite having the same effect on the terms of trade, lead to an increase in the relative price of the home consumption bundle - an effect absent under nominal devaluation. This difference is of no consequence for the real allocation when trade is balanced or when the devaluation is unexpected and asset markets are incomplete, as neither risk-sharing nor saving decisions are affected under these circumstances. As a result, precisely in these two cases, we can dispense with the adjustment in consumption taxes.

By contrast, with expected devaluations, in the absence of an adjustment in consumption taxes, the different behavior of the real exchange rate under nominal and fiscal devaluations induces different savings and portfolio decisions. These effects then need to be undone with a reduction in consumption taxes. This allows to fully mimic the behavior of the real exchange rate under a nominal devaluation. When the consumption tax is used, an offsetting increase in income taxes is required so as not to distort the labor supply decision of households.

In the case of incomplete markets we highlight the role of the currency denomination of debt. When bonds are denominated in the foreign currency or in the case of equities, no additional instruments are required for a fiscal devaluation. By contrast when international bonds are denominated in the home currency, the proposed set of tax instruments does not suffice. Equivalence then requires a partial default by the home country.

Importantly, when all four taxes (e.g., VAT, payroll, consumption and income taxes) are used, the policy is revenue-neutral for the government. That is the direct effects of tax changes on the fiscal deficit add up to zero as the revenue earned from the VAT and income tax increases exactly offset the revenue declines that follow the payroll and consumption tax cuts. The indirect effects on revenue that arise from the stimulative effects of a fiscal devaluation on output, however, remain exactly as in the case of an exchange rate devaluation. When only a reduced set of tax instruments is used, such as VAT and payroll tax only, a 
fiscal devaluation generates positive fiscal revenues in states when the country runs a trade deficit.

We consider a series of extensions that are important for implementation. One of these is the implementation of fiscal devaluations by individual countries in a currency union in a multi-country environment. We show that equivalence is retained for effects on countries both within and outside the union across nominal and fiscal devaluations. We also show that when the devaluing country is small relative to the overall size of the currency union and/or where seigniorage income constitutes a negligible share of a country's GDP, a country within a currency union can engineer a fiscal devaluation unilaterally without any coordination with the union central bank.

Finally, we provide a numerical illustration of fiscal devaluations by calibrating to the recent experience of Spain. We allow for capital and adjustment costs in capital accumulation and realistic taxes in an environment with wage rigidity. The 2008 crisis is modeled as the outcome of a borrowing cost shock that generates a decline in output, consumption and investment similar to those observed in Spain. We show that a nominal devaluation of $10 \%$ eliminates the output decline and essentially replicates the flexible wage allocation. We then compare welfare changes across various cases of complete and incomplete fiscal devaluations.

The paper proceeds as follows. Section 2 outlines the model. Section 3 presents the main equivalence results. Section 4 analyzes several extensions, such as implementation in the currency union, capital inputs, and asymmetric pass-through of taxes. Section 5 provides a numerical illustration of the equilibrium dynamics under nominal and fiscal devaluations against that under fixed exchange rates and passive fiscal policy. Section 6 concludes. Technical proofs are relegated to the appendix. ${ }^{6}$

Related literature: The tariff-cum-export subsidy and the VAT increase-cum-payroll tax reduction are intuitive fiscal policies to replicate the effects of a nominal devaluations on international relative prices, and accordingly have been discussed before in the policy and academic literature. Poterba, Rotemberg, and Summers (1986) emphasize the fact that tax changes that would otherwise be neutral if prices and wages were flexible have shortrun macroeconomic effects when prices or wages are sticky. Most recently, Staiger and Sykes (2010) explore the equivalence using import tariffs and export subsidies in a partial equilibrium static environment with sticky or flexible prices, and under balanced trade. While the equivalence between a uniform tariff-cum-subsidy and a devaluation has a long

\footnotetext{
${ }^{6}$ A supplementary online appendix, available on the authors websites, contains omitted standard derivations and additional results, including a simple static model to illustrate the main results of this paper.
} 
tradition in the literature (as surveyed in Staiger and Sykes, 2010), most of the earlier analysis was conducted in static endowment economies (or with fixed labor supply). ${ }^{7}$ Our departure from this literature is to perform a dynamic general equilibrium analysis with varying degrees of price rigidity, alternative asset market assumptions and for expected and unexpected devaluations.

This paper is complementary to Adao, Correia, and Teles (2009) who show that the allocation in the flexible price, flexible exchange rate economy can be implemented with fiscal and monetary policies that induce stable producer prices and constant exchange rates. ${ }^{8}$ This general implementation principle however does not help answer the question of whether there is a robust and small set of conventional fiscal instruments that can replicate the effect of a nominal devaluation which is the focus of our paper. Importantly, in Adao, Correia, and Teles (2009), since optimal policy is sensitive to the details of the environment, the fiscal instruments used will vary across environments and in general will require time-varying and firm-varying taxes, in contrast to the main results in our paper. ${ }^{9}$

Our paper also complements the work of Schmitt-Grohé and Uribe (2011), who show that in an environment with downward wage rigidity and inelastic labor supply, the effects of a nominal devaluation can be replicated with a payroll subsidy alone, a result that does not extend to the more general environment considered in our paper. Finally, our work is also related to Lipińska and von Thadden (2009), Franco (2011) and Boscam et al. (2011) who quantitatively evaluate the effects of a tax swap from direct (payroll) taxes to indirect taxes (VAT) under a fixed exchange rate.

\section{Model}

The model economy features two countries, home $H$ and foreign $F$. There are three types of agents in each economy: consumers, producers and the government, and we describe each in turn. We then discuss which assumptions of our setup can be further relaxed.

\footnotetext{
${ }^{7}$ The VAT policy with border adjustment has been the focus of Grossman (1980) and Feldstein and Krugman (1990), however, in an environment with flexible exchange rates and prices. Berglas (1974) provides an equivalence argument for nominal devaluations, using VAT and tariff-based policies, in a reduced-form model without micro-foundations. Calmfors (1998) provides a policy discussion of the potential role of VAT and payroll taxes in impacting allocations in a currency union.

${ }^{8}$ Eggertsson (2004) makes a similar observation in a simplified log-linearized model. In the same spirit, Correia, Farhi, Nicolini, and Teles (2011) build on the general implementation results of Correia, Nicolini, and Teles (2008) to replicate the effects of the optimal monetary policy at the zero-lower bound.

${ }^{9}$ In addition, the policy implementation in Adao, Correia, and Teles (2009) requires taxes both at Home and in Foreign. By contrast, our fiscal devaluation policies rely only on adjusting taxes at Home, which is an important practical advantage, as these policies can be implemented unilaterally. Furthermore, their implementation relies on income taxes and differential consumption taxes for local versus imported goods. These taxes are less conventional than payroll and value-added taxes-tax instruments that have been proposed as potential candidates in policy circles (e.g., see IMF, 2011).
} 


\subsection{Consumers}

The home country is populated with a continuum of symmetric households. Households are indexed by $h \in[0,1]$, but we often omit the index $h$ to simplify exposition. In each period, each household $h$ chooses consumption $C_{t}$, money $M_{t}$ and holdings of assets $\left\{B_{t+1}^{j}\right\}_{j \in J_{t}}$, where $J_{t}$ is the set of assets $J_{t}$ available to the households. Each household also sets a wage rate $W_{t}(h)$ and supplies labor $N_{t}(h)$ in order to satisfy demand at this wage rate.

The household $h$ maximizes expected lifetime utility, $\mathbb{E}_{0} \sum_{t=0}^{\infty} \beta^{t} U\left(C_{t}, N_{t}, m_{t}\right)$, subject to the flow budget constraint:

$$
\frac{P_{t} C_{t}}{1+\varsigma_{t}^{c}}+M_{t}+\sum_{j \in J_{t}} Q_{t}^{j} B_{t+1}^{j} \leq \sum_{j \in J_{t-1}}\left(Q_{t}^{j}+D_{t}^{j}\right) B_{t}^{j}+M_{t-1}+\frac{W_{t} N_{t}}{1+\tau_{t}^{n}}+\frac{\Pi_{t}}{1+\tau_{t}^{d}}+T_{t},
$$

where $P_{t}$ is the consumer price index before consumption subsidy $\varsigma_{t}^{c}$ and $m_{t}=M_{t}\left(1+\varsigma_{t}^{c}\right) / P_{t}$ denotes real money balances. $\Pi_{t}$ is aggregate profits of the home firms assumed (without loss of generality) to be held by the representative domestic consumer; $\tau_{t}^{n}$ is the labor-income tax, $\tau_{t}^{d}$ is the profit (dividend-income) tax, and $T_{t}$ is the lump-sum transfer from the government. An asset $j$ is characterized by its price $Q_{t}^{j}$ and effective payout $D_{t}^{j}$ reflecting possible defaults and haircuts on the asset.

For convenience of exposition we adopt the following standard utility specification:

$$
U\left(C_{t}, N_{t}, m_{t}\right)=\frac{1}{1-\sigma} C_{t}^{1-\sigma}-\frac{\kappa}{1+\varphi} N_{t}^{1+\varphi}+\frac{\chi}{1-\nu} m_{t}^{1-\nu} .
$$

Consumption $C_{t}$ is an aggregator of home and foreign goods:

$$
C_{t}=\left[\gamma_{H}^{\frac{1}{\zeta}} C_{H t}^{\frac{1-\zeta}{\zeta}}+\gamma_{F}^{\frac{1}{\zeta}} C_{F t}^{\frac{1-\zeta}{\zeta}}\right]^{\frac{\zeta}{\zeta-1}}, \quad \zeta \geq 0
$$

that allows for a home bias, $\gamma_{H}=1-\gamma_{F} \in[1 / 2,1]$. The consumption of both home and foreign goods is given by CES aggregators of individual varieties $i \in[0,1]$ with elasticity of substitution $\rho>1: C_{k t}=\left[\int_{0}^{1} C_{k t}(i)^{(\rho-1) / \rho} \mathrm{d} i\right]^{\rho /(\rho-1)}$ for $k \in\{H, F\}$.

We now discuss some of the relevant equilibrium conditions associated with consumers' optimal decisions. Given the CES structure of consumption aggregators, consumer good demand is characterized by:

$$
C_{k t}(i)=\left(\frac{P_{k t}(i)}{P_{k t}}\right)^{-\rho} C_{k t}, \quad C_{k t}=\gamma_{k}\left(\frac{P_{k t}}{P_{t}}\right)^{-\rho} C_{t},
$$

where $i$ is the variety of the home or foreign good $(k \in\{H, F\}) . P_{k t}(i), P_{k t}$ and $P_{t}$ are respectively the price of variety $i$ of good $k$, the price index for good $k$ and the overall consumer price index. As is well known, CES price indexes are defined by

$$
P_{t}=\left[\gamma_{H} P_{H t}^{1-\zeta}+\gamma_{F} P_{F t}^{1-\zeta}\right]^{\frac{1}{1-\zeta}} \quad \text { and } \quad P_{k t}=\left[\int_{0}^{1} P_{k t}(i)^{1-\rho} \mathrm{d} i\right]^{\frac{1}{1-\rho}}, \quad k \in\{H, F\}
$$


and the aggregate consumer expenditure is given by $P_{t} C_{t}=P_{H t} C_{H t}+P_{F t} C_{F t}$ with $P_{k t} C_{k t}=$ $\int_{0}^{1} P_{k t}(i) C_{k t}(i) \mathrm{d} i$.

It is useful to define the nominal stochastic discount factor of a household:

$$
\Theta_{t, s} \equiv \beta^{s-t}\left(\frac{C_{t+s}}{C_{t}}\right)^{-\sigma} \frac{P_{t}}{P_{t+s}} \frac{1+\varsigma_{t+s}^{c}}{1+\varsigma_{t}^{c}}, \quad s \geq t,
$$

and we use $\Theta_{t+1} \equiv \Theta_{t, t+1}$ for brevity. This discount factor prices available assets:

$$
Q_{t}^{j}=\mathbb{E}_{t}\left\{\Theta_{t+1}\left(Q_{t+1}^{j}+D_{t+1}^{j}\right)\right\}, \quad \forall j \in J_{t} .
$$

Finally, money demand is given by

$$
\chi C_{t}^{\sigma}\left(\frac{M_{t}}{P_{t} /\left(1+\varsigma_{t}^{c}\right)}\right)^{-\nu}=1-\mathbb{E}_{t} \Theta_{t+1},
$$

where the right-hand side is an increasing function of the nominal risk-free interest rate which satisfies $1+i_{t+1}=1 / \mathbb{E}_{t} \Theta_{t+1}$.

Foreign households We assume that foreign households face a symmetric problem with the exception that the foreign government imposes no taxes or subsidies and foreign consumers have a home bias towards foreign-produced goods. We denote foreign variables with an asterisk. For brevity we omit listing all equilibrium conditions for foreign given the symmetry with home. Define $J_{t}^{*}$ to be the set of assets available to foreign households and $\Omega_{t} \subset J_{t} \cap J_{t}^{*}$ to be the set of assets traded internationally by both domestic and foreign households. The equilibrium in the world asset market requires $B_{t}^{j}+B_{t}^{* j}=0$ for all $j \in \Omega_{t}$ since we assume all assets are in zero net supply.

The foreign-currency nominal stochastic discount factor is given by

$$
\Theta_{t, s}^{*}=\beta^{s-t}\left(\frac{C_{s}^{*}}{C_{t}^{*}}\right)^{-\sigma} \frac{P_{t}^{*}}{P_{s}^{*}}
$$

Since the Euler equations (4) for assets $j \in \Omega_{t}$ are satisfied for both countries, we can write international risk sharing conditions as:

$$
\mathbb{E}_{t}\left\{\frac{Q_{t+1}^{j}+D_{t+1}^{j}}{Q_{t}^{j}}\left[\Theta_{t+1}-\Theta_{t+1}^{*} \frac{\mathcal{E}_{t}}{\mathcal{E}_{t+1}}\right]\right\}=0 \quad \forall j \in \Omega_{t},
$$

where $\mathcal{E}_{t}$ is the nominal exchange rate, and the foreign currency depreciation rate $\left(\mathcal{E}_{t} / \mathcal{E}_{t+1}\right)$ converts the home-currency asset returns into foreign-currency returns. The risk sharing condition (7) states that domestic and foreign stochastic discount factors agree in pricing the internationally-traded assets. It also implicitly assumes that any default or haircut is uniform for domestic and foreign holders of the assets, and that the adopted fiscal policies do not act as capital controls. 


\subsection{Producers}

In each country there is a continuum $i \in[0,1]$ of firms producing different varieties of goods using a technology with labor as the only input. Specifically, firm $i$ produces according to

$$
Y_{t}(i)=A_{t} Z_{t}(i) N_{t}(i)^{\alpha}, \quad 0<\alpha \leq 1
$$

where $A_{t}$ is the aggregate country-wide level of productivity, $Z_{t}(i)$ is idiosyncratic firm productivity shock, and $N_{t}(i)$ is the firm's labor input. Productivity $A_{t},\left\{Z_{t}(i)\right\}$ and their foreign counterparts follow arbitrary stochastic processes over time.

The firm sells to both the home and foreign market. Specifically, it must satisfy demand (1) for its good in each market given its price $P_{H t}(i)$ at home and $P_{H t}^{*}(i)$ abroad in the foreign currency. Therefore, we can write the market clearing for variety $i$ as: ${ }^{10}$

$$
Y_{t}(i)=C_{H t}(i)+C_{H t}^{*}(i)
$$

where $C_{H t}^{*}(i)$ is foreign-market demand for variety $i$ of the home good. The profit of firm $i$ is given by

$$
\Pi_{t}^{i}=\left(1-\tau_{t}^{v}\right) P_{H t}(i) C_{H t}(i)+\left(1+\varsigma_{t}^{x}\right) \mathcal{E}_{t} P_{H t}^{*}(i) C_{H t}^{*}(i)-\left(1-\varsigma_{t}^{p}\right) W_{t} N_{t}(i),
$$

where $\tau_{t}^{v}$ is the value-added tax (VAT), $\varsigma_{t}^{x}$ is the export subsidy and $\varsigma_{t}^{p}$ is the payroll subsidy. Note that this equation makes it explicit that exports are not subject to the VAT, or more specifically VAT is rebated back to the firms upon exporting. ${ }^{11}$ We define the prices to be inclusive of the VAT, export subsidy and import tariff, but exclusive of the consumption subsidy $\varsigma_{t}^{c}$. Aggregate profits of the home firms are given by $\Pi_{t} \equiv \int_{0}^{1} \Pi_{t}^{i} \mathrm{~d} i$ and aggregate labor demand is $N_{t}=\int_{0}^{1} N_{t}(i) \mathrm{d} i$.

\subsection{Price and wage setting}

Firms set prices subject to a Calvo friction: in any given period, a firm can adjust its prices with probability $1-\theta_{p}$, and maintains its previous-period price otherwise. The firm sets prices to maximize the expected net present value of profits conditional on no price change, $\sum_{s=t}^{\infty} \theta_{p}^{s-t} \mathbb{E}_{t}\left\{\Theta_{t, s} \Pi_{s}^{i} /\left(1+\tau_{s}^{d}\right)\right\}$, subject to the production technology and demand equations given above, and where $\tau_{s}^{d}$ is the dividend-income (or profit) tax payed by stock holders.

We now need to make an assumption regarding the currency of price-setting. We assume that domestic prices are always set in the currency of the consumer and inclusive of the VAT

\footnotetext{
${ }^{10}$ Note that overall demand for good $i$ results from aggregation of demands across all consumers $h \in[0,1]$ in the home and foreign markets respectively, e.g. $C_{H t}(i)=\int_{0}^{1} C_{H t}(i ; h) \mathrm{d} h$.

${ }^{11}$ The profit of the foreign firm is $\Pi_{t}^{i *}=P_{F t}^{*}(i) C_{F t}^{*}(i)+\frac{1-\tau_{t}^{v}}{\left(1+\tau_{t}^{m}\right) \mathcal{E}_{t}} P_{F t}(i) C_{F t}^{*}(i)-W_{t}^{*} N_{t}^{*}(i)$ in foreign currency, and its exports are subject to both the VAT and the import tariff $\tau_{t}^{m}$ paid at the border.
} 
tax. We denote the domestic period $t$ reset price of firm $i$ by $\bar{P}_{H t}(i)$, so that firm's $i$ current price is given by

$$
P_{H t}(i)= \begin{cases}P_{H, t-1}(i), & \mathrm{w} / \operatorname{prob} \theta_{p} \\ \bar{P}_{H t}(i), & \mathrm{w} / \operatorname{prob} 1-\theta_{p}\end{cases}
$$

The foreign price can be set either in the producer currency, often referred to as producer currency pricing (PCP), or in the local currency, referred to as local currency pricing (LCP).

Producer currency pricing Consistent with the standard definition of PCP we assume that the firm chooses the home-currency reset price $\bar{P}_{H t}$, while the foreign-market price satisfies the law of one price:

$$
P_{H t}^{*}(i)=P_{H t}(i) \frac{1}{\mathcal{E}_{t}} \frac{1-\tau_{t}^{v}}{1+\varsigma_{t}^{x}}
$$

where $\mathcal{E}_{t}$ is the nominal exchange rate defined as the price of one unit of foreign currency in terms of units of home currency, hence higher values of $\mathcal{E}_{t}$ correspond to home currency depreciation. In words, the firm sets a common price $\bar{P}_{H t}(i)$ for both markets, and its foreign-market price equals this price converted into foreign currency and adjusted for border taxes - the export subsidy and the VAT reimbursement. The reset price satisfies the following optimality condition, standard in the New Keynesian literature (see Galí, 2008, and our derivation in the online supplement):

$$
\mathbb{E}_{t} \sum_{s=t}^{\infty} \theta_{p}^{s-t} \Theta_{t, s} \frac{P_{H s}^{\rho}\left(C_{H s}+C_{H s}^{*}\right)}{1+\tau_{s}^{d}}\left[\left(1-\tau_{s}^{v}\right) \bar{P}_{H t}(i)-\frac{\rho}{\rho-1} \frac{\left(1-\varsigma_{s}^{p}\right) W_{s}}{\alpha A_{s} Z_{s}(i) N_{s}(i)^{\alpha-1}}\right]=0
$$

This implies that the preset price $\bar{P}_{H t}(i)$ is a constant markup over the weighted-average expected future marginal costs during the period for which the price is in effect. Equations (11)-(13) together with the definition of the price index in (2), describe the evolution of home firms' prices in the home and foreign markets under PCP.

Local currency pricing Under LCP the firm sets both a home-market price $\bar{P}_{H t}(i)$ in home currency and a foreign-market price $\bar{P}_{H t}^{*}(i)$ in foreign currency. During periods of non-adjustment, the foreign-market price remains constant in foreign currency, therefore movements in the nominal exchange rates and border taxes directly affect the relative price of the firm in the home and foreign markets. As a result, the law of one price (12) is violated in general. Profit maximization with respect to $\bar{P}_{H t}(i)$ and $\bar{P}_{H t}^{*}(i)$ leads to two optimality conditions, one for the home-market price and the other for the foreign-market price (see 
the online supplement):

$$
\begin{array}{r}
\mathbb{E}_{t} \sum_{s=t}^{\infty} \theta_{p}^{s-t} \Theta_{t, s} \frac{P_{H s}^{\rho} C_{H s}}{1+\tau_{s}^{d}}\left[\left(1-\tau_{s}^{v}\right) \bar{P}_{H t}(i)-\frac{\rho}{\rho-1} \frac{\left(1-\varsigma_{s}^{p}\right) W_{s}}{\alpha A_{s} Z_{s}(i) N_{s}(i)^{\alpha-1}}\right]=0, \\
\mathbb{E}_{t} \sum_{s=t}^{\infty} \theta_{p}^{s-t} \Theta_{t, s} \frac{\left(P_{H s}^{*}\right)^{\rho} C_{H s}^{*}}{1+\tau_{s}^{d}}\left[\left(1+\varsigma_{s}^{x}\right) \mathcal{E}_{s} \bar{P}_{H t}^{*}(i)-\frac{\rho}{\rho-1} \frac{\left(1-\varsigma_{s}^{p}\right) W_{s}}{\alpha A_{s} Z_{s}(i) N_{s}(i)^{\alpha-1}}\right]=0,
\end{array}
$$

describing the evolution of prices (combined with (11), now for both markets) under LCP.

Foreign firms As for price setting by foreign firms, the reset prices of each foreign variety in the foreign market $\bar{P}_{F t}^{*}(i)$ and in the home market $\bar{P}_{F t}(i)$ are characterized in a symmetric manner to that of the home economy, with the exception that all foreign tax rates are kept at zero. Under PCP, the law of one price holds for all foreign varieties:

$$
P_{F t}(i)=P_{F t}^{*}(i) \mathcal{E}_{t} \frac{1+\tau_{t}^{m}}{1-\tau_{t}^{v}},
$$

where $\tau_{t}^{m}$ is home's import tariff charged at the border together with the home's VAT $\tau_{t}^{v}$ imposed on the foreign imports. Under LCP, foreign firms set their home-market price in home currency according to:

$$
\mathbb{E}_{t} \sum_{s=t}^{\infty} \theta_{p}^{s-t} \Theta_{t, s}^{*} P_{F s}^{\rho} C_{F s}\left[\frac{1-\tau_{s}^{v}}{1+\tau_{s}^{m}} \frac{1}{\mathcal{E}_{s}} \bar{P}_{F t}(i)-\frac{\rho}{\rho-1} \frac{W_{s}^{*}}{\alpha A_{s}^{*} Z_{s}^{*}(i) N_{s}^{*}(i)^{\alpha-1}}\right]=0 .
$$

Labor demand and wage setting Tha labor input $N_{t}$ is a CES aggregator of the individual varieties supplied by each household, $N_{t}=\left[\int_{0}^{1} N_{t}(h)^{(\eta-1) / \eta} \mathrm{d} h\right]^{\eta /(\eta-1)}$ with $\eta>1$. Therefore, aggregate demand for each variety of labor is given by

$$
N_{t}(h)=\left(\frac{W_{t}(h)}{W_{t}}\right)^{-\eta} N_{t}
$$

where $N_{t}$ is aggregate labor demand in the economy, $W_{t}(h)$ is the wage rate charged by household $h$ for its variety of labor services and $W_{t}=\left[\int_{0}^{1} W_{t}(h)^{1-\eta} \mathrm{d} h\right]^{1 /(1-\eta)}$ is the wage for a unit of aggregate labor input in the home economy. The aggregate wage bill in the economy is given by $W_{t} N_{t}=\int_{0}^{1} W_{t}(h) N_{t}(h) \mathrm{d} h$.

Households are subject to a Calvo friction when setting wages: in any given period, they may adjust their wage with probability $1-\theta_{w}$, and maintain the previous-period nominal wage otherwise. The optimality condition for wage setting is given by (see the online supplement):

$$
\mathbb{E}_{t} \sum_{s=t}^{\infty} \theta_{w}^{s-t} \Theta_{t, s} N_{s} W_{s}^{\eta(1+\varphi)}\left[\frac{\eta}{\eta-1} \frac{1}{1+\varsigma_{s}^{c}} \kappa P_{s} C_{s}^{\sigma} N_{s}^{\varphi}-\frac{1}{1+\tau_{s}^{n}} \frac{\bar{W}_{t}(h)^{1+\eta \varphi}}{W_{s}^{\eta \varphi}}\right]=0 .
$$


This implies that the wage $\bar{W}_{t}(h)$ is preset as a constant markup over the expected weightedaverage between future marginal rates of substitution between labor and consumption and aggregate wage rates, during the duration of the wage. This is a standard result in the New Keynesian literature, as derived, for example, in Galí (2008). Wage setting (19), together with the wage evolution analogous to (11), characterize equilibrium wage dynamics.

\subsection{Government and country budget constraint}

We assume that the government must balance its budget each period, returning all seigniorage and tax revenues in the form of lump-sum transfers to the households $\left(T_{t}\right)$. This is without loss of generality since Ricardian equivalence holds in this model. The government budget constraint in period $t$ is

$$
M_{t}-M_{t-1}+T R_{t}=T_{t}
$$

where $M_{t}-M_{t-1}$ is seigniorage income from money supply. The tax revenues from distortionary taxes $T R_{t}$ are given by

$$
\begin{aligned}
T R_{t}= & \left(\frac{\tau_{t}^{n}}{1+\tau_{t}^{n}} W_{t} N_{t}+\frac{\tau_{t}^{d}}{1+\tau_{t}^{d}} \Pi_{t}-\frac{\varsigma_{t}^{c}}{1+\varsigma_{t}^{c}} P_{t} C_{t}\right) \\
& +\left(\tau_{t}^{v} P_{H t} C_{H t}-\varsigma_{t}^{p} W_{t} N_{t}\right)+\left(\frac{\tau_{t}^{v}+\tau_{t}^{m}}{1+\tau_{t}^{m}} P_{F t} C_{F t}-\varsigma_{t}^{x} \mathcal{E}_{t} P_{H t}^{*} C_{H t}^{*}\right),
\end{aligned}
$$

where the first bracket contains income taxes levied on and the consumption subsidy paid to home households; the next two terms are the value-added tax paid by and the payroll subsidy received by home firms; the last two terms are the import tariff and the VAT paid by foreign exporters and the export subsidies to domestic firms.

Combining this together with the household budget constraint and aggregate profits, we arrive at the aggregate country budget constraint:

$$
\sum_{j \in \Omega_{t}} Q_{t}^{j} B_{t+1}^{j}-\sum_{j \in \Omega_{t-1}}\left(Q_{t}^{j}+D_{t}^{j}\right) B_{t}^{j}=\mathcal{E}_{t} P_{H t}^{*} C_{H t}^{*}-P_{F t} C_{F t} \frac{1-\tau_{t}^{v}}{1+\tau_{t}^{m}},
$$

where the right-hand side is the trade surplus of the home country and the left-hand side is the change in the international asset position of the home country. ${ }^{12}$

This completes the description of the setup of the model. Given initial conditions and home and foreign government policies - taxes and money supply - the equations above characterize equilibrium price and wage dynamics in the economy. Given prices firms satisfy product demand in domestic and foreign markets, and given wages households satisfy labor

\footnotetext{
${ }^{12}$ Formally, $B_{t}^{j}=\int_{0}^{1} B_{t}^{j}(h) \mathrm{d} h$ is the aggregate net foreign asset- $j$ position of home households.
} 
demand of firms. Asset prices are such that asset markets are in equilibrium given asset demand by home and foreign households, and consumer money demand equals money supply in both markets.

\subsection{Assumptions}

Before turning to the results of our analysis, we highlight that several of the assumptions made in the model setup to ease exposition can be generalized without impacting our results. These include assumptions on:

Functional forms We assume CES consumption aggregators and monopolistic competition, but the results hold under more general environments. For instance, our results generalize to the case of monopolistic competition with non-constant desired markups (e.g., as under Kimball, 1995, demand), as well as to the case of oligopolistic competition with strategic complementarities (e.g., as in Atkeson and Burstein, 2008). Departing from CES consumption aggregators and monopolistic competition substantially increases the notational burden, but leaves the analysis largely unchanged. We can also allow for a general non-separable utility function in consumption and labor without altering conclusions. We have assumed home bias in preferences, but no non-tradable goods or trade costs, yet our results immediately extend to these more general economies. ${ }^{13}$ Similarly, we have adopted a money-in-the-utility framework where real money balances are separable from consumption and leisure, but all results are unchanged when money is introduced via a cash-in-advance constraint.

Government policy instruments We formulate our model using money supply as the instrument of monetary policy (money supply rule) in both countries. We could alternatively have performed our analysis using interest rate rules or exchange rate rules without any alterations to our equivalence results. ${ }^{14}$ As in the New Keynesian literature, in our environment, the nominal interest rate is the only money market variable relevant for the rest of the allocation. Consequently, we could also focus on the cashless limit, to which our equivalence results also apply. We further discuss some of these issue in Section 4.1. For simplicity, we start from a situation where initial taxes are zero and characterize the required changes in taxes, but all the results generalize to a situation where initial taxes are not zero (see footnote 23 ).

\footnotetext{
${ }^{13}$ Note that non-tradable goods are equivalent in our analysis to domestic goods produced for domestic market, and require no special treatment in the design of a fiscal devaluation.

${ }^{14}$ See Benigno, Benigno, and Ghironi (2007) for the design of an interest rate rule to maintain a fixed exchange rate.
} 
Price setting frictions Our results generalize to departures from Calvo price and wage setting. Any model of time-contingent price adjustment with arbitrary heterogeneity in price adjustment hazard rates would deliver similar results. It can also be generalized to a menu cost model in which the menu cost is given in real units, e.g. in labor, as is commonly assumed, since in this case the decision to adjust prices will depend only on real variables (including relative prices) which stay unchanged across nominal and fiscal devaluations. Furthermore, our equivalence results also apply in other environments where devaluations have real effects without nominal frictions, as for example in the neoclassical model of Feenstra (1985) with cash-in-advance constraints in home and foreign currency. ${ }^{15}$ In Section 4.3 we discuss further extensions to our price-setting assumptions.

\section{Fiscal Devaluations}

In this section we formally define the concept of a fiscal devaluation and present our main results on the equivalence between nominal and fiscal devaluations, first for complete and then for incomplete asset markets, as well as for the special case of a one-time unanticipated devaluation. We complete the section with the discussion of government revenue neutrality of fiscal devaluations.

Definition Consider an equilibrium path of the model economy described above, along which the nominal exchange rate follows

$$
\mathcal{E}_{t}=\mathcal{E}_{0}\left(1+\delta_{t}\right) \quad \text { for } \quad t \geq 0
$$

for some (stochastic) sequence $\left\{\delta_{t}\right\}_{t \geq 0}$. Here $\delta_{t}$ denotes the percent nominal devaluation of the home currency relative to period 0 . We refer to such an equilibrium path as a nominal $\left\{\delta_{t}\right\}$-devaluation. Denote by $\left\{M_{t}\right\}$ the path of home money supply that is associated with the nominal devaluation. A fiscal $\left\{\delta_{t}\right\}$-devaluation is a sequence $\left\{M_{t}^{\prime}, \tau_{t}^{m}, \varsigma_{t}^{x}, \tau_{t}^{v}, \varsigma_{t}^{p}, \varsigma_{t}^{c}, \tau_{t}^{n}, \tau_{t}^{d}\right\}_{t \geq 0}$ of money supply and taxes that achieves the same equilibrium allocation of consumption, output and labor supply, but for which the equilibrium exchange rate is fixed, $\mathcal{E}_{t}^{\prime} \equiv \mathcal{E}_{0}$ for all $t \geq 0$. Note that, in general, we do not restrict the path of the exchange rate under a nominal devaluation. ${ }^{16}$

Before formulating and proving our main results, we manipulate the two equilibrium conditions which play the central role in our analysis. First, we divide the home country

\footnotetext{
${ }^{15}$ In this environment Feenstra (1985) studied how the tariff policy could improve over a nominal devaluation.

${ }^{16}$ For example, one can examine simple one-time devaluations with $\delta_{t}=0$ for $t<T$ and $\delta_{t}=\delta$ for $t \geq T$ with some stochastic or deterministic $T \geq 0$.
} 
budget constraint $(22)$ by $P_{t}^{*} \mathcal{E}_{t}$ to obtain:

$$
\sum_{j \in \Omega_{t}} q_{t}^{j *} B_{t+1}^{j}-\sum_{j \in \Omega_{t-1}}\left(q_{t}^{j *}+d_{t}^{j *}\right) B_{t}^{j}=\frac{P_{H t}^{*}}{P_{t}^{*}}\left[C_{H t}^{*}-C_{F t} \mathcal{S}_{t}\right]
$$

where $q_{t}^{j *}=Q_{t}^{j} /\left(P_{t}^{*} \mathcal{E}_{t}\right)$ and $d_{t}^{j *}=D_{t}^{j} /\left(P_{t}^{*} \mathcal{E}_{t}\right)$ are real prices and payouts of assets in units of the foreign final good; and

$$
\mathcal{S}_{t} \equiv \frac{P_{F t}}{P_{H t}^{*}} \frac{1}{\mathcal{E}_{t}} \frac{1-\tau_{t}^{v}}{1+\tau_{t}^{m}}
$$

is the home's terms of trade - the ratio of the import price index to the export price index adjusted for border taxes. Second, we rewrite the international risk sharing conditions (7) using the definitions of the home and foreign stochastic discount factors (3) and (6):

$$
\mathbb{E}_{t}\left\{\frac{q_{t+1}^{j *}+d_{t+1}^{j *}}{q_{t}^{j *}}\left[\left(\frac{C_{t+1}}{C_{t}}\right)^{-\sigma} \frac{\mathcal{Q}_{t+1}}{\mathcal{Q}_{t}}-\left(\frac{C_{t+1}^{*}}{C_{t}^{*}}\right)^{-\sigma}\right]\right\}=0 \quad \forall j \in \Omega_{t}
$$

where

$$
\mathcal{Q}_{t} \equiv \frac{P_{t}^{*} \mathcal{E}_{t}}{P_{t} /\left(1+\varsigma_{t}^{c}\right)}
$$

is the consumer-price real exchange rate.

These conditions highlight the role of the two international relative prices - the terms of trade $\mathcal{S}_{t}$ in shaping the trade balance on the right-hand side of the country budget constraint (23) and the real exchange rate $\mathcal{Q}_{t}$ in the international risk sharing condition (25). The exact roles of these two relative prices changes as we consider different asset market structures. But a fiscal devaluation will, in general, need to mimic the behavior of these two relative prices to replicate the equilibrium allocation resulting from a nominal devaluation.

\subsection{Complete asset markets}

In this case we assume that countries have access to a full set of one-period Arrow securities and there is perfect risk sharing across countries.

Proposition 1 Under complete international asset markets, and for both producer and local currency pricing, a fiscal $\left\{\delta_{t}\right\}$-devaluation can be achieved by one of the two policies:

$$
\begin{array}{ll}
\tau_{t}^{m}=\varsigma_{t}^{x}=\varsigma_{t}^{c}=\tau_{t}^{n}=\tau_{t}^{d}=\delta_{t}, & \text { or } \\
\tau_{t}^{v}=\varsigma_{t}^{p}=\frac{\delta_{t}}{1+\delta_{t}}, \quad \varsigma_{t}^{c}=\tau_{t}^{n}=\delta_{t} & \text { and } \quad \tau_{t}^{d}=0,
\end{array}
$$

as well as a suitable choice of $\left\{M_{t}^{\prime}\right\}$, for $t \geq 0$. 
The formal proof, contained in Appendix A.1, demonstrates that both fiscal devaluation options $\left\{\mathcal{E}_{t}^{\prime}, \tau_{t}^{m}, \varsigma_{t}^{x}, \tau_{t}^{v}, \varsigma_{t}^{p}, \varsigma_{t}^{c}, \tau_{t}^{n}, \tau_{t}^{d}\right\}$ and a nominal devaluation $\left\{\mathcal{E}_{t}, \mathbf{0}\right\}$ satisfy the equilibrium system under the same allocation of output, consumption and labor supply. This means that taxes in both the tariff-based $\left(\mathrm{FD}^{\prime}\right)$ and VAT-based $\left(\mathrm{FD}^{\prime \prime}\right)$ policies affect the equilibrium conditions exactly in the same way as changes in the exchange rate, and in particular, cancel each other out from the equilibrium conditions not directly affected by the exchange rate.

The reason the combinations of taxes in $\left(\mathrm{FD}^{\prime}\right)$ and $\left(\mathrm{FD}^{\prime \prime}\right)$ support a fiscal devaluation is that they ensure that all reset prices and wages remain the same, and given unchanged prices the rest of the allocation also remains unchanged. Indeed, to leave the wage setting in (19) unchanged requires the parity between the labor income tax and the consumption subsidy $\left(\tau_{t}^{n}=\varsigma_{t}^{c}\right)$, a policy change that keeps the labor wedge unaltered. Analogously, domestic price setting in (13) requires the parity between the VAT and the payroll subsidy $\left(\tau_{t}^{v}=\varsigma_{t}^{p}\right)$. Now consider international price setting, where the VAT or the border taxes need to mimic the effects of an exchange rate movement on both export and import prices:

$$
\frac{1+\varsigma_{t}^{x}}{1-\tau_{t}^{v}}=\frac{1+\tau_{t}^{m}}{1-\tau_{t}^{v}}=\frac{\mathcal{E}_{t}}{\mathcal{E}_{0}}=1+\delta_{t}
$$

Indeed, tax policies satisfying (27) result in the same international prices under both PCP (see (12) and (16)) and LCP (see (15) and (17)). The taxes described so far are sufficient to replicate the path of all nominal prices and wages, as well as the terms of trade in (24), but not the real exchange rate in (26), which additionally requires the use of the consumption subsidy, $\varsigma_{t}^{c}=\delta_{t}$. This summarizes the logic behind the policies in $\left(\mathrm{FD}^{\prime}\right)$ and $\left(\mathrm{FD}^{\prime \prime}\right) .{ }^{17}$

Under complete markets, the international risk sharing condition (25) becomes the familiar Backus-Smith condition:

$$
\left(\frac{C_{t}}{C_{t}^{*}}\right)^{\sigma}=\lambda \mathcal{Q}_{t},
$$

which ties the relative consumptions of the two countries to the real exchange rate, and where the constant $\lambda$ is recovered from the intertemporal budget constraint of the country, which depends on relative prices and in particular the evolution of the terms of trade (see Appendix A.1). This implies that the consumption allocation also remains unchanged under $\left(\mathrm{FD}^{\prime}\right)$ and $\left(\mathrm{FD}^{\prime \prime}\right)$ relative to a nominal devaluation, given that, as we established, these policies leave unchanged all prices, including the terms of trade and the real exchange rate. And once we have established that $\left\{C_{t}, C_{t}^{*}\right\}$ follows the same path, consumptions and outputs of every variety, as well as labor demand and supply, must also follow the same path to satisfy good and labor demand conditions given unchanged wages and prices.

\footnotetext{
${ }^{17}$ Under complete markets, the use of the profit tax $\tau_{t}^{d}$ is merely needed to avoid second-order distortions in price setting under the tariff-based policy $\left(\mathrm{FD}^{\prime}\right)$.
} 
For a more intuitive narrative, let us consider a particular price setting environment, namely PCP. In this case an exchange rate devaluation at home depreciates home's terms of trade. As home's import price rises relative to its export price, there is an expenditure switching effect that reallocates home and foreign demand towards home goods. This is the standard channel through which exchange rate depreciations have expansionary effects on the economy. A fiscal devaluation mimics the same movement in the terms of trade (24), which under PCP we rewrite using the law of one price conditions (12) and (16) as:

$$
\mathcal{S}_{t}=\frac{P_{F t}^{*}}{P_{H t}} \mathcal{E}_{t} \frac{1+\varsigma_{t}^{x}}{1-\tau_{t}^{v}}
$$

Given the producer currency prices $P_{H t}$ and $P_{F t}^{*}$, a fiscal devaluation requires either $\tau_{t}^{v}=$ $\delta_{t} /\left(1+\delta_{t}\right)$ or $\varsigma_{t}^{x}=\tau_{t}^{m}=\delta_{t}$. That is, an exchange rate depreciation given producer prices raises the relative price of home imports to home exports. A fiscal devaluation generates the same relative price adjustment by means of either an increase in VAT or imposition of an import tariff and export subsidy. The VAT affects international relative prices because it is both reimbursed to home exporters and imposed at the border on home importers of foreign goods, and hence no additional border tax (import tariff or export subsidy) is required when the VAT is used. An increased VAT must be coupled with a payroll subsidy $\varsigma_{t}^{p}=\tau_{t}^{v}$ in order to avoid a negative wedge in the home price setting and good supply, absent under a nominal devaluation.

The use of the consumption subsidy $\varsigma_{t}^{c}$ is important for replicating the behavior of the real exchange rate, which depreciates under a nominal devaluation with sticky prices. Indeed, without the use of the consumption subsidy, both the import tariff and the VAT policies, despite mimicking the terms of trade movement, raise the home price level by making foreign goods more expansive. This results in an appreciated real exchange rate which needs to be undone by the consumption subsidy. The use of the consumption subsidy however distorts the wage setting and labor supply decision, which needs to be offset using a proportional labor income tax, $\tau_{t}^{n}=\varsigma_{t}^{c}=\delta_{t}$. In the presence of international risk sharing, the movement in the real exchange rate matters for the relative consumption allocation across countries, and consequently the consumption subsidy is essential. However, there are two cases when mimicking the real exchange rate, and hence using the consumption subsidy and income tax, is not essential for the equivalence. The first is the case of financial autarky and balanced trade which we discuss in Appendix A.2; the second is the case of incomplete international asset markets under an unanticipated devaluation which we study in detail in Section 3.3.

Discussion We now highlight some interesting features about our equivalence result. First, a surprising finding is that the same policies work under both LCP and PCP, independently 
of whether the law of one price holds. This is because the policies replicate not only the terms of trade, but also the deviations from the law of one price, whenever they exist under LCP, and all relative prices more generally. Note however that despite the equivalence result holding independently of pricing assumptions, the allocations under LCP and PCP can be substantially different (as discussed, for example, in Lane, 2001). In particular, under PCP the terms of trade depreciates with a devaluation, while under LCP it appreciates on impact (see Obstfeld and Rogoff, 2000).

Secondly, fiscal devaluations mimic not only real variables and relative prices, but also nominal prices. This is because under the staggered price setting environment replicating the path of nominal prices is essential in order not to distort relative prices, and hence relative output, across firms that do and do not adjust prices. As a consequence, since fiscal devaluations mimic all nominal prices, the standard redistribution concerns associated with inflation are identical across fiscal and nominal devaluations.

Third, the fiscal devaluation policies depend only on $\left\{\delta_{t}\right\}$, the desired devaluation sequence, and not directly on the details of the model economy. In this sense, fiscal devaluation policies are robust - they are insensitive to the micro structure of the economy and require little information about it. The optimal size of the devaluation, however, depends on model details.

Finally, we emphasize that a fiscal devaluation requires no active adjustment to money supply, and the path of home money supply is determined endogenously by equilibrium money demand in (5) given the decision of the home central bank to implement a particular path of the exchange rate under respectively a nominal and a fiscal devaluation. ${ }^{18}$ We return to the discussion of monetary policy rules sustaining a fiscal devaluation in Section 4.1.

\subsection{Incomplete asset markets}

We now consider the case of incomplete asset markets. The equivalence result follows closely that of Proposition 1 under complete markets, and in general terms can be stated as follows:

Lemma 1 Under arbitrary asset markets, both $\left(\mathrm{FD}^{\prime}\right)$ and $\left(\mathrm{FD}^{\prime \prime}\right)$ constitute $\left\{\delta_{t}\right\}$-fiscal devaluation policies as long as the foreign-currency payoffs of all internationally-traded assets $\left\{D_{t}^{j *}\right\}$ are unchanged.

\footnotetext{
${ }^{18}$ The path of the money supply under a fiscal devaluation is, in general, different from that under a nominal devaluation, which however is not consequential for the rest of the allocation when money enters the utility function separably. Under the alternative assumption, or if we additionally required to replicate the path of the real money holdings, the equivalence requires the use of an additional tax on money holdings to mimic the reduced money demand under an expected nominal devaluation (see Appendix A.1).
} 
Proof: As we show in the proof of Proposition 1, $\left(\mathrm{FD}^{\prime}\right)$ and $\left(\mathrm{FD}^{\prime \prime}\right)$ replicate changes in all relative prices including the terms of trade and the real exchange rate. The same arguments go through in the case of incomplete markets as the relevant equilibrium conditions are the same. The main difference with the complete markets case is that now the general versions of the country budget constraint and international risk sharing conditions (23) and (25) apply. As long as real asset payoffs and prices $\left\{d_{t}^{j *}, q_{t}^{j *}\right\}$ are unchanged in terms of the foreign final good, conditions (23) and (25) are satisfied under the original allocation $\left\{C_{t}, C_{t}^{*}\right\}$ and the original asset demand $\left\{B_{t}^{j}\right\}$. Since under these policies $\left\{P_{t}^{*}\right\}$ is unchanged, it is enough to require that $\left\{D_{t}^{j *}, Q_{t}^{j *}\right\}$ are unchanged where $D_{t}^{j *}=d_{t}^{j *} P_{t}^{*}$ is the foreign-currency nominal payoff of an asset. Finally, the fundamental price of the asset satisfies

$$
Q_{t}^{j *}=\sum_{s \geq t} \mathbb{E}_{t}\left\{\Theta_{t, s}^{*} D_{s}^{j *}\right\}=P_{t}^{*} \sum_{s \geq t} \mathbb{E}_{t}\left\{\beta^{s-t}\left(\frac{C_{s}^{*}}{C_{t}^{*}}\right)^{-\sigma} \frac{D_{s}^{j *}}{P_{s}^{*}}\right\}
$$

hence under no-bubble asset pricing we only need to require that the path of foreign-currency nominal asset payoffs $\left\{D_{t}^{j *}\right\}$ is unchanged.

Our equivalence results therefore apply to settings with arbitrarily rich, albeit incomplete, financial markets. Solving for international portfolio choice under these settings is notoriously complicated (e.g., see discussion in Devereux and Sutherland, 2008). Nevertheless, our analysis goes through as we do not need to characterize the solution, but merely verify whether an allocation that is an equilibrium outcome under one set of policies remains an equilibrium allocation under another set of policies.

We next can consider a variety of asset market structures in view of Lemma 1. First consider one-period risk-free foreign-currency nominal bond. This bond pays $D_{t+1}^{f *} \equiv 1$ in foreign currency and its foreign-currency price is $Q_{t}^{f *}=\mathbb{E}_{t}\left\{\Theta_{t+1}^{*}\right\}=1 /\left(1+i_{t+1}^{*}\right)$, where $i_{t+1}^{*}$ is the foreign-currency risk-free nominal interest rate. This asset satisfies requirements in Lemma 1, and hence $\left(\mathrm{FD}^{\prime}\right)$ and $\left(\mathrm{FD}^{\prime \prime}\right)$ constitute fiscal devaluation policies without additional instruments. The same applies to long-term foreign-currency debt as well.

Next consider one-period home-currency risk-free bond with a payoff of $D_{t+1}^{h}=1$ in home currency, and hence $D_{t+1}^{h *}=1 / \mathcal{E}_{t+1}$ in foreign-currency. This asset does not satisfy Lemma 1, and hence we need to introduce partial default (haircut $\tau_{t}^{h}$ ) to make its foreigncurrency payoff the same as under a nominal devaluation. A haircut policy on one-period home-currency debt that is required for equivalence satisfies:

$$
1-\tau_{t+1}^{h} \equiv \frac{\mathcal{E}_{t}}{\mathcal{E}_{t+1}} \quad \Leftrightarrow \quad \tau_{t+1}^{h}=\frac{\delta_{t+1}-\delta_{t}}{1+\delta_{t+1}}
$$


i.e., the haircut at $t+1$ equals the incremental percent devaluation in that period. With this haircut, the equilibrium payoff of the home-currency debt under a fiscal devaluation is

$$
D_{t+1}^{h *}=1-\tau_{t+1}^{h}=\frac{1+\delta_{t}}{1+\delta_{t+1}}
$$

and hence its foreign-currency price becomes

$$
Q_{t}^{h *}=\mathbb{E}_{t}\left\{\Theta_{t+1}^{*}\left(1-\tau_{t+1}^{h}\right)\right\}=\left(1+\delta_{t}\right) \mathbb{E}_{t}\left\{\Theta_{t+1}^{*} /\left(1+\delta_{t+1}\right)\right\}
$$

This haircut keeps the returns on the bond $\left(D_{t+1}^{h *} / Q_{t}^{h *}\right)$ unchanged in the foreign currency across nominal and fiscal devaluations, which is sufficient to ensure the rest of the equivalence. Note that the partial default in (29) exactly replicates the valuation effects on home-currency assets associated with exchange rate movements (e.g., see Gourinchas and Rey, 2007). ${ }^{19}$

As the last example, we consider international trade in equities, for which: ${ }^{20}$

$$
D_{t}^{h e *}=\frac{\Pi_{t}}{\left(1+\tau_{t}^{d}\right) \mathcal{E}_{t}} \quad \text { and } \quad D_{t}^{f e *}=\Pi_{t}^{*} .
$$

From equations (10) for profits and its foreign counterpart, we observe that both $\left(\mathrm{FD}^{\prime}\right)$ and $\left(\mathrm{FD}^{\prime \prime}\right)$ keep both $\Pi_{t} /\left[\left(1+\tau_{t}^{d}\right) \mathcal{E}_{t}\right]$ and $\Pi_{t}^{*}$ unchanged relative to a nominal devaluation, and hence the conditions of Lemma 1 are satisfied without additional instruments. Indeed, the VAT-cum-payroll subsidy under $\left(\mathrm{FD}^{\prime \prime}\right)$ reduces the foreign-currency profits of home firms, just like a nominal devaluation. Similarly, the profit (dividend-income) tax does the same under a tariff-based devaluation $\left(\mathrm{FD}^{\prime}\right)$. This, in particular, replicates the distributional and balance-sheet effects of a nominal devaluation.

We summarize the results above in:

Proposition 2 Under trade in foreign-currency risk-free bonds and international trade in equities, a fiscal $\left\{\delta_{t}\right\}$-devaluation can be achieved by the same polices $\left(\mathrm{FD}^{\prime}\right)$ and $\left(\mathrm{FD}^{\prime \prime}\right)$ as under complete markets; with trade in home-currency bonds, $\left(\mathrm{FD}^{\prime}\right)$ and $\left(\mathrm{FD}^{\prime \prime}\right)$ need to be complemented with a partial default (haircut) equal to $\tau_{t}^{h}=\left(\delta_{t}-\delta_{t-1}\right) /\left(1+\delta_{t}\right)$ on all outstanding home-currency debt.

\footnotetext{
${ }^{19}$ Under a representative agent economy, it is sufficient to require a partial default (haircut) only on all internationally held home-currency bonds; in a heterogeneous-agent economy exact equivalence requires partial default on all outstanding home-currency debt, including the within-country holdings across agents, otherwise fiscal devaluations will introduce additional distributions effects beyond those under a nominal devaluation. Further note that for long-term home-currency debt, the partial default should also extend to the principal of the debt outstanding.

${ }^{20}$ The value of the equities are given by $Q_{t}^{h e *}=\sum_{s \geq t} \mathbb{E}_{t}\left\{\Theta_{t, s}^{*} \frac{\Pi_{s}}{\left(1+\tau_{t}^{d}\right) \mathcal{E}_{t}}\right\}$ and $Q_{t}^{f e *}=\sum_{s \geq t} \mathbb{E}_{t}\left\{\Theta_{t, s}^{*} \Pi_{s}^{*}\right\}$.
} 
Full policies $\left(\mathrm{FD}^{\prime}\right)$ and $\left(\mathrm{FD}^{\prime \prime}\right)$ robustly engineer fiscal devaluations under both complete and incomplete markets. ${ }^{21}$ We next study one special case under which the set of policy instruments needed to implement a fiscal devaluation can be substantially reduced.

\subsection{One-time unanticipated devaluation}

Consider the case of a one-time unanticipated $\delta$-devaluation at $t=0$. Under these circumstances, prior to $t=0$, the devaluation is completely unexpected (i.e., a zero probability event), while at $t=0$ the exchange rate devalues by $\delta$ once and for all future periods and states. As we now show, a fiscal devaluation under these circumstances imposes a substantially weaker requirement on the set of fiscal instruments - in particular, the consumption subsidy and the income tax can be dispensed with - as long as asset markets are incomplete in the sense that they do not allow for international transfers targeted specifically to the zero-probability event of an unanticipated devaluation.

Proposition 3 Under incomplete markets, a one-time unanticipated fiscal $\delta$-devaluation may be attained with one of the two reduced policies:

$$
\begin{aligned}
\tau_{t}^{m}=\varsigma_{t}^{x}=\tau_{t}^{d}=\delta \quad \text { and } \quad \varsigma_{t}^{c}=\tau_{t}^{n}=0, \quad \text { or } \\
\tau_{t}^{v}=\varsigma_{t}^{p}=\frac{\delta}{1+\delta} \quad \text { and } \quad \varsigma_{t}^{c}=\tau_{t}^{n}=\tau_{t}^{d}=0,
\end{aligned}
$$

coupled with a partial default (haircut) $\tau_{0}^{h}=\delta /(1+\delta)$ on home-currency debt and an unchanged path of money supply $M_{t}^{\prime}=M_{t}$, for $t \geq 0$.

See Appendix A.3 for the formal proof of this proposition. The main difference of the reduced policies $\left(\mathrm{FD}_{R}^{\prime}\right)$ and $\left(\mathrm{FD}_{R}^{\prime \prime}\right)$ from the full policies in Propositions 1 and 2 , is that the consumption subsidy and income tax can be dispensed with. This is because under an unanticipated devaluation we have one less relative price to replicate and that is the real exchange rate. Note that international risk sharing (25) is unaffected by a one-time unanticipated jump in the real exchange rate in the event of a devaluation, provided that international asset markets are incomplete. As a result, only the path of the terms of trade, but not of the real exchange rate, has to be mimicked in this case.

Intuitively, the terms of trade is the relative price affecting the terms of exchange in a given state, as reflected in the flow budget constraint (23). In contrast, the real exchange rate is the relative price affecting savings (trade across time) and portfolio choice (risk-sharing

\footnotetext{
${ }^{21}$ As Benigno and Kucuk-Tuger (2012) highlight, the real allocations are very sensitive to small changes in the number of assets traded. Despite this, the fiscal equivalence propositions remain the same across arbitrary degrees of asset market completeness.
} 
across states of the world), as reflected in (25). Since the devaluation is unanticipated, savings and portfolio choice decisions are unaffected prior to the devaluation (for $t<0$ ). Furthermore, as it is a one-time permanent devaluation, after it happens at $t=0$ the future dynamics of the real exchange rate, $\mathcal{Q}_{t+1} / \mathcal{Q}_{t}$ for $t \geq 0$, remains the same under a reduced fiscal devaluation as under a nominal devaluation. Consequently, the savings and portfolio choice decisions are also unaffected for $t \geq 0$, and the jump in $\mathcal{Q}_{t}$ at $t=0$ remains inconsequential for the equilibrium allocation. This is why the consumption subsidy can be dispensed with, and by consequence the income tax is also not needed since there is no labor supply wedge to offset. ${ }^{22}$

Implementability Arguably, the reduced VAT-based policy $\left(\mathrm{FD}_{R}^{\prime \prime}\right)$ under a one-time unanticipated devaluation is the most practical from a policy perspective. Indeed, it requires only a one-time change in two widely used tax rates - an increase in the value-added tax and a reduction in the payroll tax. The requirement, however, is that these tax changes are equally unanticipated, and in Section 5 we study numerically the departures from equivalence when the fiscal adjustment happens with a lag.

It might appear that while the size of a nominal devaluation is unrestricted with $\delta \in$ $(0,+\infty)$, even in theory the size of the tax adjustment is limited as it cannot exceed $100 \%$. This is actually not the case. Theoretically a fiscal devaluation of arbitrary size $\delta \geq 0$ is also possible. For example, under $\left(\mathrm{FD}_{R}^{\prime \prime}\right)$, a $\delta$-devaluation requires setting VAT and payroll subsidy at $\delta /(1+\delta) \in(0,1) .{ }^{23}$ We further consider the issue of the plausible magnitude of a fiscal devaluation in Section 5 .

\subsection{Government revenue neutrality}

We now study how fiscal devaluations affect government revenues over and above the effects of a nominal devaluation. We first show that the full fiscal devaluation policies $\left(\mathrm{FD}^{\prime}\right)$ and $\left(\mathrm{FD}^{\prime \prime}\right)$ are exactly revenue neutral, state-by-state and period-by-period, that is lead to exactly the same effects on the government budget as a nominal devaluation. We then analyze the

\footnotetext{
${ }^{22}$ Note that consumption subsidy and income tax do not affect the country budget constraint (23) directly, but they do lead to distributional consequences between the home government and the home households, as we discuss in Section 3.4 ( $c f$. parts (i) and (ii) of Proposition 4).

${ }^{23}$ If there were initial non-zero VAT and payroll taxes in place, one can verify that the required new taxes under a fiscal $\delta$-devaluation are:$$
\tau^{v}=\frac{\bar{\tau}^{v}+\delta}{1+\delta} \quad \text { and } \quad \tau^{p}=\frac{\bar{\tau}^{p}-\delta}{1+\delta}
$$

where $\bar{\tau}^{v}$ and $\bar{\tau}^{p}$ are the pre-devaluation levels of VAT and payroll taxes. Note that for any size of devaluation $\delta$, we still have $\tau^{v}<1$ and $\varsigma^{p} \equiv-\tau^{p}<1$. The larger is the initial level of VAT, the smaller is a required further increase in the VAT to achieve a given level of devaluation.
} 
one-time unanticipated policies $\left(\mathrm{FD}_{R}^{\prime}\right)$ and $\left(\mathrm{FD}_{R}^{\prime \prime}\right)$ which do not utilize consumption and income taxes, and show that these policies generate additional tax revenues in periods (and states of the world) when the country runs trade deficits.

It is convenient to introduce the following notation:

$$
\tau_{t}^{m}=\varsigma_{t}^{x}=\tau_{t}^{d}=\delta_{t}^{m}, \quad \tau_{t}^{v}=\varsigma_{t}^{p}=\frac{\delta_{t}^{v}}{1+\delta_{t}^{v}}, \quad \varsigma_{t}^{c}=\tau_{t}^{n}=\epsilon_{t} .
$$

Under $\left(\mathrm{FD}^{\prime}\right), \delta_{t}^{m}=\epsilon_{t}=\delta_{t}$ and $\delta_{t}^{v}=0$; under $\left(\mathrm{FD}^{\prime \prime}\right), \delta_{t}^{m}=0$ and $\delta_{t}^{v}=\epsilon_{t}=\delta_{t}$. The one-time policies, $\left(\mathrm{FD}_{R}^{\prime}\right)$ and $\left(\mathrm{FD}_{R}^{\prime \prime}\right)$ differ only in that $\epsilon_{t}=0$ and $\delta_{t} \equiv \delta$ for $t \geq 0$. With this notation, we can rewrite incremental government tax revenues (21) generated from fiscal devaluations as: ${ }^{24}$

$$
T R_{t}=\left[\frac{\delta_{t}^{v}}{1+\delta_{t}^{v}}+\frac{\delta_{t}^{m}}{1+\delta_{t}^{m}}-\frac{\epsilon_{t}}{1+\epsilon_{t}}\right]\left(P_{t} C_{t}-W_{t} N_{t}\right)
$$

Given this, we prove:

Proposition 4 (i) The full fiscal devaluation policies, $\left(\mathrm{FD}^{\prime}\right)$ and $\left(\mathrm{FD}^{\prime \prime}\right)$, are exactly government revenue neutral state-by-state and in every time period. (ii) Under reduced fiscal devaluation policies, $\left(\mathrm{FD}_{R}^{\prime}\right)$ and $\left(\mathrm{FD}_{R}^{\prime \prime}\right)$, additional government revenues over and above that from a one-time unanticipated nominal devaluation equal

$$
T R_{t}=-\frac{\delta_{t}}{1+\delta_{t}} N X_{t}+\frac{\delta_{t} \Pi_{t}}{1+\tau_{t}^{d}}
$$

where $N X_{t}=\left(1+\delta_{t}\right) \mathcal{E}_{0} P_{H t}^{*} C_{H t}^{*}-P_{F t} C_{F t}$ is the trade balance of the country.

The formal prove of this proposition is contained in Appendix A.4. The first part of the proposition follows immediately from (30) when we substitute in the full fiscal devaluation policies $\left(\mathrm{FD}^{\prime}\right)$ or $\left(\mathrm{FD}^{\prime \prime}\right)$ which results in $T R_{t} \equiv 0$. The more involved case is when the reduced policies $\left(\mathrm{FD}_{R}^{\prime}\right)$ or $\left(\mathrm{FD}_{R}^{\prime \prime}\right)$ are used, which when substituted into (30) result in $T R_{t}=$ $\delta /(1+\delta) \cdot\left(P_{t} C_{t}-W_{t} N_{t}\right)$. This suggests that the additional government revenues from a reduced fiscal devaluation are proportional to the difference between total consumption and total production expenditure (equal in our case to the wage bill). The former exceeds the latter when either the country runs a trade deficit or earns aggregate profits, as formally reflected in (31). ${ }^{25}$ To summarize, a one-time unanticipated fiscal devaluation policy will generate additional fiscal revenues in the periods in which the country runs a trade deficit,

\footnotetext{
${ }^{24} \mathrm{We}$ used the fact that $P_{H t} C_{H t}+P_{F t} C_{F t}=P_{t} C_{t}$, as well as the expression for firm profits (10).

${ }^{25}$ Indeed, the VAT-cum-payroll subsidy taxes all goods supplied for consumption in the domestic market $\left(P_{t} C_{t}\right)$ and subsidizes production expenditure $\left(W_{t} N_{t}\right)$. The tariff-cum-export-subsidy is a tax on net imports $\left(-N X_{t}\right)$, while the additional dividend tax under this policy taxes profits $\left(\Pi_{t}\right)$. As Proposition 4 shows, the two policies lead to the same government revenues.
} 
as long as aggregate profits in the economy are non-negative. This is an appealing feature of this policy from a practical point of view. ${ }^{26}$

\section{Extensions}

In this section we discuss four extensions to the benchmark environment discussed in previous sections. First, we describe how to engineer a fiscal devaluation in a currency union. Second, we allow for capital as a variable input in production besides labor. Third, we discuss our tax pass-through assumptions and evaluate the case of asymmetric pass-through of VAT and payroll taxes into prices. Fourth, we allow for labor mobility.

\subsection{Fiscal devaluations in a currency union}

We now consider the implementation of a fiscal devaluation in a monetary union, where the member-countries give up their monetary policy independence and adopt a common currency hence abandoning the possibility of a nominal devaluation. ${ }^{27}$ We consider a general multicountry world economy in which a subset of countries forms a currency union, while the remaining countries maintain their own currencies and independent monetary policy.

In general, as we discussed above, a nominal devaluation requires a change in the home money supply. The distinctive feature of a currency union is that the money supply to individual member-countries becomes an endogenous variable, and the relative money supply between the countries adjust in order to satisfy the fixed nominal value of the currency within the union. The union-wide central bank controls only the overall money supply to all country members, or alternatively a union-wide nominal interest rate. The questions we ask in this section are whether the same policies we studied before still constitute a fiscal devaluation and whether a coordinated policy action from the union central bank is required.

To summarize our findings up front, the same fiscal devaluation policies proposed earlier are still effective in a currency union. Furthermore, in a cashless world in which monetary authorities follow interest rate rules, any member of a currency union can implement a fiscal devaluation unilaterally without coordination from the union central bank. However, more generally, away from the cashless limit, a fiscal devaluation by a member of a currency union needs to be accommodated by an increase in money supply by the union central bank (automatic under an interest-rate rule) and a corresponding transfer of the extra seigniorage

\footnotetext{
${ }^{26}$ This also implies, as we show in Appendix A.4, that the net present value of additional fiscal surpluses from an unanticipated fiscal devaluation is non-negative when the value of the country's business sector (stock market capitalization plus the value of unincorporated business) exceeds its net foreign liabilities, which is easily satisfied for the majority of developed countries.

${ }^{27}$ For a recent survey of the literature on currency unions see Silva and Tenreyro (2010).
} 
revenues from the union central bank to the country-member implementing a fiscal devaluation. In Section 5 we show in a calibrated model that the effects of these seigniorage transfers are negligible, and the unilateral fiscal policy comes very close to replicating a devaluation.

In the case of multiple countries, two clarifications need to be made. First, the equivalence now refers to the following two counterfactual scenarios: in one, a country is a member of a larger currency union and implements a fiscal devaluation; and in the other, the country is not part of the union (e.g., leaves the union) and implements a nominal devaluation against the currency of the union, while all other members of the union remain a part of it. $^{28}$ Second, the equivalence result allows for arbitrary monetary policy rules in countries outside the currency union. In particular, the equivalence extends to the equilibrium path in countries outside the currency union and among other variables holds for nominal exchange rates of these countries against the currency union. ${ }^{29}$

We now provide the formal extension of the model environment to the case of multiple countries and the generalization of the fiscal devaluation results.

Setup and additional notation Consider a world consisting of $N_{U}+N_{F}+1$ countries which we denote by $k \in\left\{0, \ldots, N_{U}+N_{F}\right\} \equiv \mathbb{W}$, where $N_{U} \geq 1$ and $N_{F} \geq 1$. We denote by $\mathcal{E}_{t}^{k, k^{\prime}}$ a bilateral nominal exchange rate between countries $k, k^{\prime} \in \mathbb{W}$ in units of currency $k$ for one unit of currency $k^{\prime}$. $N_{U}$ countries form a currency union $\mathbb{U}=\left\{1, \ldots, N_{U}\right\}$ and hence have $\mathcal{E}_{t}^{k, k^{\prime}} \equiv 1$ for all $k, k^{\prime} \in \mathbb{U}$. We denote the exchange rate between the union currency and a country $k \in \mathbb{W} \backslash \mathbb{U}$ outside the currency union by $\mathcal{E}_{t}^{U, k}$. $N_{F}$ countries, $k \in$ $\left\{N_{U}+1, \ldots, N_{U}+N_{F}\right\} \equiv \mathbb{F}$, follow independent monetary policies (money supply or interest rate rules) and hence have floating currencies. The remaining country, $k=0$, chooses between two regimes. First, it may choose to manage its exchange rate against the currency union, $\mathcal{E}_{t}^{0, U}$, in particular carry out a dynamic devaluation $\delta_{t}=\mathcal{E}_{t}^{0, U}$, where we normalize for simplicity $\mathcal{E}_{0}^{0, U}=1$. Second, it may choose to be part of the currency union (hence have $\left.\mathcal{E}_{t}^{0, U} \equiv 1\right)$ and carry out a fiscal $\delta_{t}$-devaluation. We denote by $\tilde{\mathbb{U}} \equiv \mathbb{U} \cup\{0\}$ the extended currency union in this case, and $\tilde{\mathbb{U}}=\mathbb{U}$ in the alternative case when country 0 has an independent monetary policy.

In terms of notation relative to Section 2, we now use country index $k \in \mathbb{W}$ on all

\footnotetext{
${ }^{28}$ The alternative scenario is when all countries leave the union, which we do not consider here since it results in a large number of possible counterfactual equilibrium pathes depending on the monetary policy adopted by each country leaving the currency union.

${ }^{29}$ Pinning down the specific equilibrium path of the nominal exchange rates between the currency union and the outside countries requires details of the micro environment and the policy rules used, which we do not need for our equivalence result. The union central bank can always target its average nominal exchange rate with a given set of trade partners (or a single trade partner), in which case a fiscal devaluation by a member of the currency union results in an equivalent devaluation against this set of trade partners.
} 
country-specific variables (previously we had no identifier for home and star for foreign). We only need to generalize the expression for the consumption of the imported goods, which now becomes an index:

$$
C_{F t}^{k}=\left[\sum_{k^{\prime} \in \mathbb{W} \backslash\{k\}} \gamma_{k, k^{\prime}}^{1 / \zeta^{*}}\left(C_{F, t}^{k, k^{\prime}}\right)^{\frac{1-\zeta^{*}}{\zeta^{*}}}\right]^{\frac{\zeta^{*}}{1-\zeta^{*}}}, \quad \sum_{k^{\prime} \in \mathbb{W} \backslash\{k\}} \gamma_{k, k^{\prime}}=1,
$$

where $\zeta^{*}$ is the elasticity of substitution between foreign varieties of the good, which in general can be different from both $\zeta$ and $\rho$. Each of the $C_{F, t}^{k, k^{\prime}}$ is a CES aggregator of individual country- $k^{\prime}$ varieties with elasticity of substitution $\rho$, a natural generalization to the two-country setup. The price indexes $P_{F, t}^{k}$ are generalized appropriately.

The remaining equilibrium conditions are largely unchanged, in particular, this concerns the consumer and country budget constraints, risk sharing conditions, money demand, price and wage setting, as well as the expressions for the terms of trade and the CPI-based real exchange rate. Each country has a stochastic discount factor $\Theta_{t, s}^{k}$, and now the risk sharing conditions (7) must be satisfied for each pair of countries and for each internationally traded asset.

What is different now, is the role of the union central bank that provides money supply $M_{t}^{U}$ to satisfy money demands $M_{t}^{k}$ in the member-countries:

$$
M_{t}^{U}=\sum_{k \in \tilde{\mathbb{U}}} M_{t}^{k} .
$$

The central bank collects seigniorage revenues from money supply and redistributes it back to the member-countries:

$$
M_{t}^{U}-M_{t-1}^{U}=\sum_{k \in \tilde{\mathbb{U}}} \Omega_{t}^{k}
$$

where $\Omega_{t}^{k}$ is the transfer to country $k$.

Consequently, the government budget constraint of country $k \in \tilde{\mathbb{U}}$ instead of (20) becomes

$$
\Omega_{t}^{k}+T R_{t}^{k}=T_{t}^{k}
$$

where $T R_{t}^{k} \equiv 0$ when the country does not attempt a fiscal devaluation. That is, when part of a currency union, the revenues of the government from seigniorage under an independent monetary policy are replaced with the transfers of a share in the union-wide seigniorage revenues. The government budget constraint for countries outside the currency union stays unchanged. We assume that these countries follow independent monetary policy rules - formulated in terms of money supply, interest rate or exchange rate - which can be conditioned on any variable, nominal or real, with the exception of the bilateral nominal 
exchange rate with country 0 , which is not well-defined when it is part of a currency union. The rules can, however, condition on the exchange rate with the currency union.

Fiscal devaluations in a currency union Consider an equilibrium in this economy, when country 0 is not part of the currency union. In this case, we have an equilibrium path for exchange rates $\left\{\mathcal{E}_{t}^{U, k}, \mathcal{E}_{t}^{0, k}\right\}_{k \in \mathbb{F}}$ and $\mathcal{E}_{t}^{0, U}=\delta_{t}$ (with initial normalization $\mathcal{E}_{0}^{0, U}=$ $\delta_{0}=1$ ), which satisfy the no arbitrage relation, $\mathcal{E}_{t}^{0, k}=\delta_{t} \cdot \mathcal{E}_{t}^{U, k}$. Therefore, a nominal $\left\{\delta_{t}\right\}$ devaluation against the currency union results in a devaluation of size $\delta_{t} \cdot \mathcal{E}_{t}^{U, k} / \mathcal{E}_{0}^{U, k}$ against country $k$, which depends on the movement of union-country- $k$ exchange rate, $\mathcal{E}_{t}^{U, k} / \mathcal{E}_{0}^{U, k}$. This equilibrium path is associated with an allocation $\left\{C_{t}^{k}, Y_{t}^{k}, N_{t}^{k}\right\}_{k \in \mathbb{W}}$ supported by prices, asset values and money.

We now define a fiscal devaluation by country 0 when it is a part of the currency union and hence $\mathcal{E}_{t}^{U, 0} \equiv 1$. In this case, a fiscal devaluation policy involves the same set of fiscal instruments as in Section 3 used by country 0, as well as the money supply and seigniorage transfers by the union central bank, $\left\{M_{t}^{U \prime}, \Omega_{t}^{k \prime}\right\}_{t \geq 0, k \in \tilde{U}}$, which result in the same equilibrium path $\left\{C_{t}^{k}, Y_{t}^{k}, N_{t}^{k}\right\}_{k \in \mathbb{W}}$ as a nominal $\left\{\delta_{t}\right\}$-devaluation against the currency union. We prove the following generalization:

Proposition 5 The fiscal devaluation policies in Propositions 1-3 still constitute a fiscal $\left\{\delta_{t}\right\}$-devaluation in a currency union, provided that the union central bank follows

$$
M_{t}^{U \prime}=M_{t}^{0 \prime}+\sum_{k \in \mathbb{U}} M_{t}^{k} \quad \text { and } \quad \Omega_{t}^{0 \prime}=\Delta M_{t}^{0 \prime}
$$

where $M_{t}^{0 \prime}$ is the money supply under a fiscal devaluation, as in Propositions 1-3 respectively. Money supply in all other countries $\left(M_{t}^{k}, k \in \mathbb{W} \backslash\{0\}\right)$ and seigniorage transfers to the other members of the currency union $\left(\Omega_{t}^{k}, k \in \mathbb{U}\right)$ are the same as under the nominal devaluation.

We omit the proof of this proposition for brevity, as it follows the same steps as the proof of Proposition 1 and Lemma 1 by noting that the country budget constraints (23) and international risk sharing conditions (25) generalize directly to the multi-country case, as well as the country's terms of trade (24) and real exchange rate (26). ${ }^{30}$ Note that the fiscal devaluation policy must affect international transactions symmetrically vis-à-vis all trade partners of the country, both inside and outside the currency union. For example, an increase in the VAT needs to be applied to all imports (reimbursed on all exporters) independently of the country of origin (destination).

\footnotetext{
${ }^{30}$ The additional requirement of Lemma 1 that the payoffs of all assets remain the same in the foreign currency is now modified to allow for any country's currency foreign to the devaluing country. Therefore, under incomplete markets, debt in any currency other than country 0 does not require additional instruments, while debt in home currency of country 0 still requires a partial default.
} 
The distinctive feature of a fiscal devaluation in a currency union is that now the union central bank needs to increase the money supply exactly to accommodate the increase in money demand in country 0 triggered by the fiscal devaluation policy, as well as transfer the additional seigniorage revenues to country 0 . The union central bank does not need to worry about the distribution of the money supply between the members of the currency union, as this happens endogenously given the fixed exchange rate (common currency) between the member-countries. ${ }^{31}$

The same outcome can be obtained with a union-wide interest rate rule, by setting a path for $i_{t+1}^{U}$. In this case, the equivalence requires no active monetary policy response from the union central bank, but merely that it follows the same $i_{t+1}^{U}$-policy rule as under the alternative scenario of the nominal devaluation, which endogenously results in the path of money supply $\left\{M_{t}^{U \prime}\right\}$ supporting a fiscal devaluation. ${ }^{32}$ This is, of course, a more practical case, which also better fits the reality of monetary policy in the world.

The transfer of additional seigniorage revenues is, in general, needed even under an interest rate policy rule, to keep unchanged the budget constraint of the country implementing a fiscal devaluation relative to the alternative scenario of a nominal devaluation. We now provide a limiting result where the seigniorage transfers are not needed. Specifically, consider the limiting case of a cashless economy by letting $\chi \rightarrow 0$ in the utility function so that the money demand (5) shrinks to zero independently of consumption and interest rate. In this case seigniorage revenues are also arbitrary small, and consequently seigniorage transfers become inessential. We then have:

Proposition 6 Consider a cashless economy $(\chi=0)$, in which the union central bank follows a monetary policy rule resulting in a given equilibrium path of the nominal interest rate, $\left\{i_{t+1}^{U}\right\}$. Then a member-country of the currency union can attain a fiscal devaluation unilaterally without coordination from the union central bank, by means of fiscal policies described in Propositions 1-3.

In Section 5 we study the importance of violating the seigniorage transfer requirement in a calibrated model with $\chi>0$, and find its quantitative importance negligible for the equiv-

\footnotetext{
${ }^{31}$ In the case when country 0 is small, in the particular sense that $M_{t}^{0} / M_{t}^{U} \rightarrow 0$, the changes in $M_{t}^{0}$ do not affect $M_{t}^{U}$. Therefore, the union central bank does not need to move $M_{t}^{U}$ when a small member of the union implements a fiscal devaluation. In this case, given $M_{t}^{U}$, the money supply relocates towards the devaluing member without affecting the rest of the currency union as the devaluing country is small.

${ }^{32}$ From Lemma 1 we know that the union-currency nominal interest rate follows the same path under a nominal and a fiscal devaluation, which in particular implies that a zero-lower-bound constraint on the union interest rate policy will be binding to the same extent under a nominal and a fiscal devaluation. It is important for equivalence, however, that the union central bank follows exactly the same policy rule under a nominal and a fiscal devaluation, and does not change its objective or target across the two counterfactuals.
} 
alence result. This suggests that Proposition 6 provides a relevant point of approximation for our analysis. ${ }^{33}$

To summarize, the fiscal devaluation policies considered earlier in a two-country world where both countries preserve their monetary policy independence, extend directly to a much richer setup with multiple countries a subset of which form a currency union. With these policies, a country within a currency union can replicate the equilibrium path it could have attained by being outside the currency union and devaluing against the currency of the union. Finally, under the circumstances likely to be relevant empirically, a fiscal devaluation inside a currency union can be implemented unilaterally by any country-member of the currency union without coordination from the union central bank.

\subsection{Capital}

In this sub-section, we discuss how our characterization of fiscal devaluations change when we introduce capital into the model as an additional variable input in production. With capital, additional tax instruments are required to implement a fiscal devaluation, and we introduce these instruments below. In Section 5, we study the performance of an incomplete fiscal devaluation policy without these additional instruments in a calibrated model economy with capital and adjustment costs.

We adopt a formalization where firms frictionlessly rent the services of labor and capital on centralized spot markets, at prices $W_{t}$ and $R_{t}$, and capital is accumulated by households. The full model setup is described in the online appendix, while here we present the two central new equilibrium conditions. Given these two conditions, the remaining equilibrium conditions including price setting, country budget constraint and international risk sharing conditions are not affected.

The first of these conditions is the firm's choice of production inputs:

$$
\operatorname{MRT}_{i t}\left(N_{t}(i), K_{t}(i)\right)=\frac{\left(1-\varsigma_{t}^{R}\right) R_{t}}{\left(1-\varsigma_{t}^{p}\right) W_{t}}
$$

where $M R T_{i t}\left(N_{t}(i), K_{t}(i)\right)$ is the marginal rate of transformation of one unit of capital for one unit of labor in the production of firm $i, \varsigma_{t}^{p}$ is the payroll subsidy as before, and now $\varsigma_{t}^{R}$ is a capital subsidy (or, a subsidy on the firm capital rental expenses). Whenever the payroll subsidy is used (e.g., as in the VAT-payroll subsidy policy $\left(\mathrm{FD}^{\prime \prime}\right)$ ), it has to be complemented

\footnotetext{
${ }^{33}$ Indeed, seigniorage plays a small role as a source of government revenues in most developed countries, which motives the focus on the cashless limit in a large part of the New Keynesian literature (e.g., see Woodford, 2003).
} 
with a uniform capital subsidy:

$$
\varsigma_{t}^{R} \equiv \varsigma_{t}^{p}
$$

otherwise firms would have an incentive to substitute labor for capital in production under a fiscal devaluation - an effect absent in a nominal devaluation.

The second new condition is household optimality with respect to capital accumulation:

$$
\mathbb{E}_{t}\left\{\left(\frac{C_{t+1}}{C_{t}}\right)^{-\sigma} \frac{P_{t} /\left(1+\varsigma_{t}^{c}\right)}{P_{t+1} /\left(1+\varsigma_{t+1}^{c}\right)}\left(1+\varsigma_{t}^{I}\right)\left[\frac{R_{t+1}}{1+\tau_{t+1}^{K}}+\frac{1-d}{1+\varsigma_{t+1}^{I}}\right]\right\}=1,
$$

where $d$ is the capital depreciation rate, $\varsigma_{t}^{c}$ is the consumption subsidy as before, and now $\varsigma_{t}^{I}$ is the investment subsidy (investment tax credit) and $\tau_{t}^{K}$ is the capital-income tax. The condition above states that the return on an additional unit of physical capital discounted with the home stochastic discount factor equals one, where for simplicity we assumed no adjustment costs which we introduce in Section 5 .

As can be seen from this optimality condition, a fiscal devaluation policy requires

$$
\tau_{t}^{K} \equiv \varsigma_{t}^{I} \equiv \varsigma_{t}^{c}
$$

i.e., a capital-income tax and an investment subsidy both equal to the consumption subsidy involved. If the investment subsidy is not used together with the consumption subsidy, a fiscal devaluation distorts the household's allocation of expenditure in favor of consumption goods and away from investment goods since the relative price of the investment good increases. If the capital-income tax is not used together with the consumption subsidy, a fiscal devaluation distorts the consumption-savings decision in favor of greater capital accumulation due to increased after-tax returns on capital. Importantly, whenever the consumption subsidy is not used as part of a fiscal devaluation policy, the capital-income tax and the investment subsidy will not be used as well. We summarize these results in:

Proposition 7 In an economy with capital as a variable input in production, (i) full fiscal devaluation policies $\left(\mathrm{FD}^{\prime}\right)$ and $\left(\mathrm{FD}^{\prime \prime}\right)$ of Propositions 1-2 need to be extended with a capitalincome tax and investment subsidy, $\tau_{t}^{K} \equiv \varsigma_{t}^{I} \equiv \delta_{t}$, while $\tau_{t}^{K} \equiv \varsigma_{t}^{I} \equiv 0$ under reduced fiscal devaluation policies $\left(\mathrm{FD}_{R}^{\prime}\right)$ and $\left(\mathrm{FD}_{R}^{\prime \prime}\right)$ of Proposition 3; (ii) in addition, VAT-based fiscal devaluation policies $\left(\mathrm{FD}^{\prime \prime}\right)$ and $\left(\mathrm{FD}_{R}^{\prime \prime}\right)$ need to be complemented with a capital subsidy, $\varsigma_{t}^{R} \equiv \delta_{t} /\left(1+\delta_{t}\right)$, while tariff-based policies $\left(\mathrm{FD}^{\prime}\right)$ and $\left(\mathrm{FD}_{R}^{\prime}\right)$ need not.

If we focus on the reduced VAT-based fiscal devaluation $\left(\mathrm{FD}_{R}^{\prime \prime}\right)$ as the most practical policy, the only additional tax instrument required is the capital subsidy to firms. The general principle is that all value added inputs of the firm need to be subsidized at the same rate in order not to distort the equilibrium mix of the factors of production. 


\subsection{Tax pass-through}

We now turn to the discussion of our assumptions on the sensitivity of prices to exchange rate and tax changes, relate it to existing empirical evidence and analytically evaluate a departure from the pass-through assumptions in the main text. For concreteness, we restrict attention to the VAT-based reduced fiscal devaluation policy $\left(\mathrm{FD}_{R}^{\prime \prime}\right)$ replicating a one-time unanticipated devaluation (Proposition 3), due to its greater implementability. The propositions on equivalence rely on two sets of assumptions that would be normal to impose in a standard new Keynesian environment: One, foreign firms pass-through of exchange rate and VAT changes into the prices at which they sell to the domestic market is the same, all else equal, that is conditional on the foreign wage. Two, domestic firms pass-through of VAT and payroll tax to domestic prices is the same, conditional on the domestic wage.

In the medium and long-run, when firms adjust their prices, these assumptions are natural. When the exchange rate and tax changes are large, the long-run can be attained very quickly since firms will choose to adjust prices immediately. The question then is about the short-run, when as a large body of evidence suggests, prices adjust infrequently and respond sluggishly to shocks.

We now survey what empirical evidence exists on the short-run response of prices to exchange rate and tax policy changes. The first assumption requires symmetry of pass-through of exchange rate shocks and VAT shocks into foreign firms prices to the domestic market. Since existing papers in the literature do not directly address this question, one is necessarily comparing evidence across different data sets and more importantly comparing cases where the tax shocks and exchange rate shocks are not necessarily similarly unanticipated or anticipated. Nevertheless, what evidence exists appears to support the assumption of similar pass-through rates. For instance, Campa, Goldberg, and González-Mínguez (2005) estimate that short-run (one month) pass-through into import prices in the Euro Area is 66\% (and $81 \%$ in the long-run, after four months). Andrade, Carré, and Bénassy-Quéré (2010) examine data on French exports to the Euro zone over the 1996-2005 period and document that median pass-through of VAT shocks that occurred in eleven EMU12 partner countries over this period is $70-82 \%$ at a one year horizon. While they lack higher frequency data they conclude that the evidence is consistent with similar pass-through behavior for exchange rate and VAT shocks over a year. The evidence also appears consistent with producer currency pricing.

Evidence on the second assumption on responses of domestic prices to VAT and payroll is even harder to come by. First, while there exist some studies on VAT pass-through at various horizons there are very few equivalent studies for payroll taxes. Carbonnier (2007) 
studies two French reforms that involved steep decreases in VAT in 1987 and then in 1999 and finds that the pass-through into domestic prices, almost immediately, was $57 \%$ in the new car sales market and $77 \%$ in the household repair services market. The extent of passthrough therefore varies by market. There is however no similar evidence for payroll tax changes in these markets. Further, the tax changes were of a very large magnitude and consequently more revealing of long-run pass-through. ${ }^{34}$ The one case study that involved both a VAT increase and a payroll tax cut is the German VAT increase of 3 percentage points and a cut in employer and employee payroll contributions by 2.3 percentage points in 2007. Carare and Danninger (2008) examine the effect of these policy changes on core inflation. They find evidence of staggered price adjustment to tax shocks. The tax policies were announced 13 months ahead of actual implementation and, consistent with infrequent price adjustment, they find that prices adjusted upward prior to implementation. They conclude that overall pass-through from VAT was $73 \%$ with about half of this occurring in the run-up to implementation and the other half at the time of implementation. This evidence however cannot be directly used to shed light on the symmetry assumption. Firstly, they focus on core inflation and do not distinguish between domestic and foreign price passthrough. Secondly, they provide no evidence on pass-through of the payroll tax. Given that their identification relies on comparing VAT-effected goods with non-VAT goods, they isolate only the VAT pass-through component. This evidence also does not shed light on unanticipated tax changes.

The existing evidence therefore does not shed much light on the second assumption. Consequently, we briefly discuss how the equivalence proposition is impacted in the case of short-run asymmetry in pass-through rates between VAT and payroll tax. Specifically, we assume that firms during the period of price non-adjustment mechanically index their price changes to changes in VAT and payroll taxes:

$$
P_{H t}(i)= \begin{cases}\bar{P}_{H t}(i), & \text { if adjust, } \\ P_{H, t-1}(i)\left(\frac{1-\tau_{t}^{v}}{1-\tau_{t-1}^{v}}\right)^{-\xi_{v}}\left(\frac{1-\varsigma_{t}^{p}}{1-\varsigma_{t-1}^{p}}\right)^{\xi_{p}}, & \text { if does not adjust }\end{cases}
$$

where $\xi_{v}, \xi_{p} \in[0,1]$ are short-run tax pass-through (index) rates. Our baseline analysis of Sections 2-3 was performed under the assumption $\xi_{v}=\xi_{p}=0$. However, since our policies always involve a uniform adjustment in VAT and payroll subsidy $\left(\tau_{t}^{v}=\varsigma_{t}^{p}\right)$, the baseline results immediately extend to the case of symmetric short-run pass-through, $\xi_{v}=\xi_{p} \in[0,1]$.

We now discuss the asymmetric pass-through case, for concreteness specializing to $0 \leq$

\footnotetext{
${ }^{34}$ In September 1987, the VAT rate on car sales went down from the luxury-rate of $33.3 \%$ to the full-rate of $18.6 \%$. In September 1999, the VAT rate on housing repair services went down from the full-rate of $20.6 \%$ to the reduced-rate of $5.5 \%$
} 
$\xi_{p}<\xi_{v} \leq 1$, that is a higher short-run pass-through on VAT changes relative to payroll tax changes. Under PCP, the law of one price (12) and (16) still holds for international prices, hence requiring that the VAT adjusts exactly as in Proposition $3, \tau_{t}^{v} \equiv \delta /(1+\delta)$ for $t \geq 0$. Therefore, we need to choose a suitable dynamic path for the payroll subsidy in order to mimic the behavior of the price index for the home good in the home market, $P_{H t} .{ }^{35}$ The online supplement offers a detailed analysis, while here we only provide an expression for the path of the payroll tax when its short-run pass-through is zero, $\xi_{p}=0$ :

$$
\varsigma_{0}^{p}=1-\left(\frac{1}{1+\delta}\right)^{1+\xi_{v} / \lambda}>\frac{\delta}{1+\delta} \quad \text { and } \quad \varsigma_{t}^{p}=\tau_{t}^{v}=\frac{\delta}{1+\delta} \quad \text { for } \quad t \geq 1
$$

where $\lambda=\left(1-\theta_{p}\right)\left(1-\beta \theta_{p}\right) / \theta_{p}$ is a measure of price stickiness (i.e., the slope parameter of the New Keynesian Phillips curve; see, e.g., Galí, 2008).

The main insight from this analysis, which generalizes to the case of $\xi_{p} \in\left(0, \xi_{v}\right)$, is that with a lower pass-through of payroll taxes relative to VAT, a fiscal devaluation requires an overshooting in the payroll subsidy in the short run before it settles at its long-run level equal to the one-time increase in the VAT. This is intuitive, as the lower pass-through of payroll subsidies limits their effectiveness to curb the short-run price increase triggered by the spike in the VAT. In contrast to our results in Section 3, engineering a fiscal devaluation under asymmetric pass-through requires information about the micro structure of the economy, in particular the short-run pass-through rates $\xi_{p}$ and $\xi_{v}$, and the measure of price stickiness $\lambda$.

\subsection{Labor mobility}

Our baseline setup does not allow for labor mobility across countries, however, the analyzed fiscal devaluation policies can be extended to economies with labor mobility. Labor mobility can be introduced into the model in different ways. Consider the case in which the home workers have the option to be employed in the foreign country, but still have their consumption at home. ${ }^{36}$ In this case, the no arbitrage condition for workers requires the equalization of nominal payoffs in the two locations, $W_{t} /\left(1+\tau_{t}^{n}\right)=\mathcal{E}_{t} W_{t}^{*}$. Since as we have discussed, a fiscal devaluation needs to replicate the path of $\left\{W_{t}, W_{t}^{*}\right\}$, the use of income tax becomes essential under labor mobility. Indeed, the full policies $\left(\mathrm{FD}^{\prime}\right)$ and $\left(\mathrm{FD}^{\prime \prime}\right)$ of Propositions 1 and 2 do satisfy this requirement, and continue to implement fiscal devaluation even with

\footnotetext{
${ }^{35}$ With asymmetric pass-through, one can only achieve a first-order equivalence, mimicking the behavior of the aggregate price indexes, but not individual firm prices.

${ }^{36} \mathrm{An}$ alternative case is when workers can only choose to migrate fully, moving the location of both their employment and consumption. Since fiscal devaluations replicate all real variables and relative prices, the equivalence extends immediately to this case.
} 
labor mobility of this type. ${ }^{37}$ An important qualification in this case is that income taxes need to be based on the source of income rather than the residency of the worker.

\section{Numerical Illustration}

In this section we numerically evaluate the impact of fiscal devaluations. We compare allocations and welfare across various cases of complete and incomplete fiscal devaluations. Specifically, we consider the case when only a VAT-payroll tax swap is used with no change in capital taxes, the case of an anticipated fiscal devaluation, the case of smaller than optimal fiscal devaluation, and the case without seignorage transfer in a currency union.

To do this we calibrate a small open economy to some features of Spain and its recent experience during the crisis. This is a variant of the model in Section 2, retaining the functional forms and extended to include capital (Section 4.2). Wages are assume to be sticky and prices flexible.

The production function is Cobb-Douglas, $Y_{t}=A_{t} N_{t}^{\alpha} K_{t}^{1-\alpha}$. We in addition incorporate adjustment costs to capital and the accumulation equation for capital is given by:

$$
I_{t}=K_{t+1}-(1-\delta) K_{t}+\frac{\phi_{I}}{2}\left(\frac{K_{t+1}}{K_{t}}-\delta\right)^{2} K_{t}
$$

where $\phi_{I}$ controls the magnitude of adjustment costs to capital.

We focus on incomplete markets with only bonds denominated in the foreign currency (that is in euros) and impose that the world interest rate facing domestic households depends on the amount the country as a whole borrows. Specifically,

$$
i_{t+1}^{*}=i^{*}+\psi\left(e^{B^{*}-B_{t+1}}-1\right)+\varepsilon_{r, t},
$$

where $B^{*}$ is the steady state debt level, $i^{*}=(1 / \beta)-1$. This assumption ensures that the model is stationary: in the long run, debt returns to its steady state level following a shock. The shock to borrowing $\operatorname{costs} \varepsilon_{r, t}$ is assumed to follow an $\operatorname{AR}(1)$ with autocorrelation coefficient $\rho_{r}$.

We incorporate nonzero initial taxes. The economy is initially at a steady state with constant positive value added, payroll, capital and labor income taxes. The revenues from these taxes are rebated to households in the form of a lump-sum transfer/tax. We set all other taxes to zero. The exchange rate is pegged at 1.

\footnotetext{
${ }^{37}$ In contrast, fiscal implementation of the first best allocation in Adao, Correia, and Teles (2009) requires additional fiscal instruments under labor mobility.
} 
Table 1: Calibration values

\begin{tabular}{lcc}
\hline \hline & Parameter & Value \\
\hline Discount factor & $\beta$ & 0.98 \\
Risk aversion & $\sigma$ & 5.00 \\
Labor share & $\alpha$ & 0.75 \\
Depreciation rate & $\delta$ & 0.05 \\
Frisch elasticity of labor supply & $\varphi^{-1}$ & 0.50 \\
Disutility of labor & $\kappa$ & 1.00 \\
Home bias & $\gamma_{H}$ & 0.60 \\
Capital adjustment cost parameter & $\phi_{I}$ & 2.00 \\
Semi-elasticity of $M / P$ to $i$ & $\nu^{-1}$ & 0.2 \\
Relative weight for utility from money & $\chi$ & $5 \cdot 10^{-4}$ \\
\hline \hline
\end{tabular}

Note: other parameter values as reported in the text.

Parameter values The parameter values used in the simulation are listed in Table 1. The time period is a quarter. Several parameters take values standard in the literature (see e.g. Galí, 2008). Except when considering the flexible wage case, we follow Christiano, Eichenbaum, and Rebelo (2011) and set the wage stickiness parameter $\theta^{w}=0.85$ corresponding roughly to a year and a half average duration of wages. The elasticity of substitution across home varieties and across foreign varieties is assumed to be $\rho=4$, a value near the middle of a relatively wide range of estimates found in a large literature. ${ }^{38}$ For the elasticity of substitution across domestic and foreign varieties we assume a value of $\zeta=1.2$ to correspond to the close to 1 value estimated in Feenstra, Obstfeld, and Russ (2010).

The tax rates are calibrated to the values for Spain in 2008 as reported in European Commission (2011). The VAT rate, $\bar{\tau}^{v}$ is set to $16 \%$ which is the 'standard' VAT rate. The payroll tax, $\bar{\tau}^{p}$, is set at $18 \%$ and includes employers payroll taxes and social security contributions. The capital tax, $\bar{\tau}^{R}$, is set to $18.3 \%$ to match the implicit tax rate on capital and business income. The labor income tax rate, $\bar{\tau}_{n}$, is set to $14 \%$ to match the implicit tax rate on labor from personal income tax and employees social security contributions.

The parameters for the utility of real money balances are chosen to match the ratio of M1 to nominal GDP for the Euro area (0.36) and to be consistent with the literature that emphasizes a low semi-elasticity of real money balances to interest rates. The initial debt to GDP is calibrated to match the net foreign asset to GDP of Spain of $-75 \%$ in 2008. This corresponds to a $B=B^{*}=-0.87$

\footnotetext{
${ }^{38}$ For example, Broda and Weinstein (2006) define a product variety as the interaction of an HTS 10-digit code and country and obtain a median elasticity estimate of 2.9 and a mean elasticity estimate of 8.2.
} 
Shock At time zero, the economy is in its non-stochastic steady state. At time one, agents are hit by an unexpected shock to their cost of borrowing. Given $\rho_{r}=0.95$ to match the persistent effect of the shock, we calibrate $\varepsilon_{r}$ to match the $4 \%$ decline in GDP in Spain between 2008-2009. This corresponds to $\varepsilon_{r}=0.013$.

Results Figure 1 plots the impulse response of the economy to the interest rate shock for three cases: flexible wages (F), sticky wages (S) and sticky wages with a $10 \%$ fiscal devaluation (FD). This magnitude of devaluation mimics closely the movement in consumption in the flexible wage case. ${ }^{39}$ According to the formula in footnote 23 , a $10 \%$ fiscal devaluation translates into an increase in VAT of 7.6 percentage points (to 23.6\%), a payroll tax cut of 10.7 percentage points (to $7.3 \%$ ) and a capital tax cut of 10.8 percentage points (to $7.5 \%$ ). Note that the initial non-stochastic steady state is identical across all cases. All reported variables are in percent deviation from their steady state values.

The increase in interest rates makes borrowing costly and leads to a substitution away from consumption to savings. Since Spain is a net debtor in the initial steady state the increase in interest rates has a negative income effect that reinforces the substitution effect and further reduces consumption. The increase in interest rates leads to an increase in the required rate of return on capital (consistent with the no-arbitrage condition between saving in foreign bonds and in capital) and a decline in investment. The increase in savings and decline in investment translates into an improvement in the trade balance. The extent of the decline in consumption and investment and the impact on output and labor varies across the three specifications and is tied to differential relative price movements.

In the case when wages are flexible $(\mathrm{F})$, the decline in relative demand for home goods (given home-bias) induces a decline in the demand for labor and capital services. At the same time the decline in consumption, through the wealth effect, generates an increase in labor supply for given real wages. The combined effect is a decline in real wages (5\%) and a decline in wages relative to rental rates of capital. In our calibration the net effect is an increase in labor employment and an increase in output of $2.5 \%$. The decline in relative demand for home goods is associated with a sharp terms of trade depreciation of close to $10 \%$, consistent with the decline in nominal wages and rental rates of capital.

When wages are sticky $(\mathrm{S})$, the relative price movements are distorted because of the slow downward adjustment in wages as seen in Figure 1. The price of home goods declines by a

\footnotetext{
${ }^{39} \mathrm{~A}$ one-time devaluation (nominal or fiscal) does not perfectly replicate the flexible-wage equilibrium due to the dynamics associated with adjustment in capital. Note that, as is well known, in the presence of mark-ups and distortionary taxes, the flexible price equilibrium is not first best. Welfare under an exchange rate devaluation can therefore be higher than in the flexible price allocation.
} 

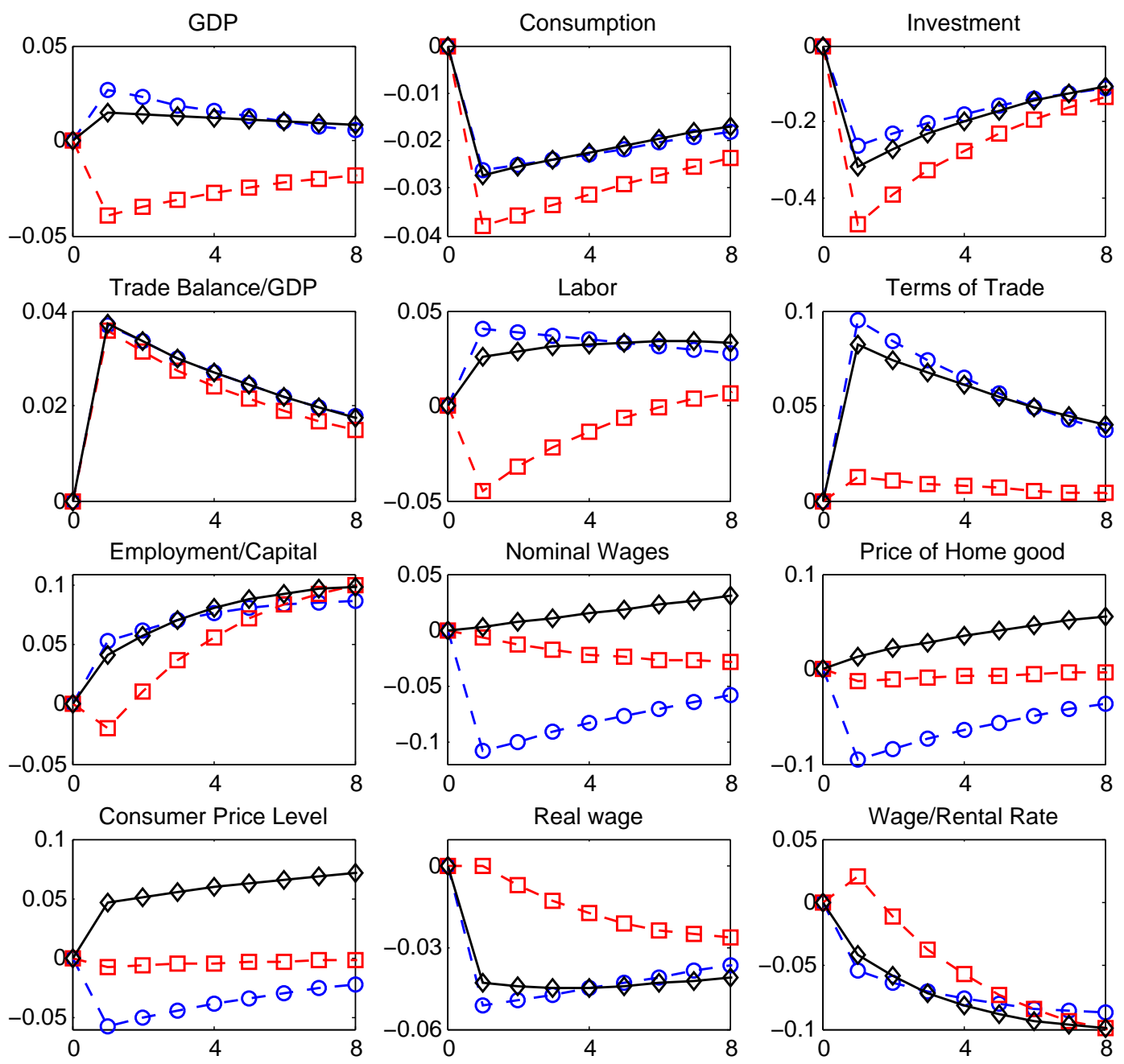

- $\ominus$ - F: Flexible wage - - - S: Sticky wage \ FD: $10 \%$ Fiscal devaluation, sticky wage

Figure 1: Impulse response to an interest rate shock

small amount and the terms of trade therefore depreciates by a little over $1 \%$ as compared to the $10 \%$ depreciation in the flexible price case. Since the terms-of-trade is over-appreciated relative to the flexible wage case the demand for domestic goods is too low. Similarly, real wages decline gradually and the ratio of wages to the rental rate of capital increases in the short-run, as opposed to decreasing as in the flexible price case. The combined effect is a $4.5 \%$ drop in labor, a $4 \%$ decline in output and a decline in the employment of labor relative to capital. The direction of movement of labor and output differs both qualitatively and quantitatively from the flexible price case. ${ }^{40}$

\footnotetext{
${ }^{40}$ It is useful to compare the sticky wage outcome to papers that have used interest rate shocks but with flexible prices. For instance, Neumeyer and Perri (2005) highlight the importance of attenuating wealth effects on labor supply to generate a negative comovement between interest rates and output. Further, they require working capital to generate the required correlation. As is evident here, with pricing power and wage rigidity, even without working capital and with preferences that allow for wealth effects on labor supply interest rate shocks can generate negative co-movement. An important difference is that wage rigidity generates inefficient relative price movements in the hiring of labor versus capital.
} 
The impulse responses in the sticky wage case line up qualitatively quite well with what was observed in Spain following the crisis. The decline in output, consumption, labor, investment and the improvement in the trade balance accord well with the facts for Spain. The model generated decline in consumption is $3.8 \%$, while in the data it is $4.9 \%$ between 2008-09. The trade balance as a ratio of GDP improves by 3.6\% in the model generated data, while empirically the improvement was $4.1 \%$. The model generates a decline in investment of $43 \%$ which is larger than in the data, where investment declined by $30 \%$ from its peak in 2007 to 2010.

The FD case is where under sticky wages, in the period when the interest rate shock hits, the country implements a one-time (unexpected) permanent $10 \%$ fiscal devaluation (FD). This intervention targets both the too-high real wage and the under-depreciated terms of trade. The devaluation raises the domestic price of imported goods and reduces the foreign price of exported goods, thus generating a larger depreciation of the terms of trade $(8 \%)$ than the case without the intervention (1.5\%). The associated increase in the home price level also brings about the relevant decline in real wages, close to the level in the flexible price case. While this one-time exchange rate intervention cannot replicate the flexible price allocations perfectly, it does quite well, as seen in the figures. The decline in consumption, investment, improvement in the trade balance to GDP, and the increase in labor, output and the ratio of employment to capital are quite close to the flexible price case.

Lastly, we evaluate the welfare impact of a 10\% devaluation (FD) relative to the case without the fiscal devaluation $(\mathrm{S})$. We perform a calculation à la Lucas (1987). That is we compute the permanent per-period decline in consumption in the non-stochastic steady state required to match the welfare following the interest rate shock, with and without the fiscal devaluation. As is well known, in standard business cycle models the level effects are quite small. The relevant number is therefore the comparison across the different cases. The certainty equivalent consumption decline in the case of $\mathrm{FD}$ is $0.45 \%$. Without the FD intervention the certainty equivalent consumption decline is around $50 \%$ higher, at $0.64 \%$. A second measure is to restrict the consumption decline to a shorter time interval (as opposed to a permanent decline). When restricted to 10 quarters, the constant per-period consumption decline (relative to the initial steady state) is $2.55 \%$. Without the fiscal devaluation, it is again around $50 \%$ higher, at $3.65 \%$. These numbers are reported in the first two rows of Table 2.

Incomplete fiscal devaluations: We now evaluate the impact of three deviations from the complete unanticipated fiscal devaluation just described. First, we look at the case 
Table 2: Welfare loss under alternative policies

\begin{tabular}{lcc}
\hline \hline & \multicolumn{2}{c}{ Consumption loss } \\
\cline { 2 - 3 } & Permanent & 10 quarters \\
\hline No intervention (S) & $-0.64 \%$ & $-3.65 \%$ \\
$10 \%$ nominal or fiscal devaluation (FD) & $-0.45 \%$ & $-2.55 \%$ \\
& Of this gap \\
\cline { 2 - 2 } - FD w/out capital tax cut $\left(\mathrm{FD}^{\tilde{K}}\right)$ & $68 \%$ \\
- Anticipated fiscal devaluation $\left(\mathrm{FD}^{A}\right)$ & $79 \%$ \\
- 5\% fiscal devaluation & \multicolumn{2}{c}{$53 \%$} \\
\hline \hline
\end{tabular}

Note: welfare-equivalent steady state consumption loss (relative to welfare under no shock).

without the adjustment in capital taxes, and only an increase in the VAT and a reduction in the payroll tax $\left(\mathrm{FD}^{\tilde{K}}\right)$. Second, we consider a one-quarter-ahead anticipated increase in the VAT and a corresponding reduction in the payroll and capital taxes $\left(\mathrm{FD}^{A}\right)$, but without any change in the consumption or income taxes, as would be required to replicate an anticipated nominal devaluation. Third, we consider an unanticipated fiscal devaluation, but excluding the seigniorage revenues from the country budget constraint $\left(\mathrm{FD}^{\tilde{M}}\right)$, to capture the case of a fiscal devaluation in a currency union without the transfer of seigniorage from the union central bank to the devaluing country (see discussion in Section 4.1).

In all these cases, as we know from the theoretical discussion, the exact equivalence between a nominal and a fiscal devaluation is violated, and we now investigate the departures from equivalence quantitatively. In the online supplement we report the impulse responses under these alternative policies, and compare them with the impulse response under a complete fiscal devaluation. The overall conclusion is that these incomplete policies generate impulse responses that track closely the dynamic path in response to a complete policy. Under $\left(\mathrm{FD}^{\tilde{K}}\right)$ the relative demand for capital is distorted, which leads to a larger drop in investment and a larger improvement in the trade balance. Anticipated policy $\left(\mathrm{FD}^{A}\right)$ generates a one-quarter decline in employment and output with a bounce back in all variables in the following period to a level very close to the dynamic path of the unanticipated fiscal devaluation (FD). The dynamic response to $\left(\mathrm{FD}^{\tilde{M}}\right)$, in the absence of seigniorage revenues, is almost indistinguishable from that under a complete policy, reflecting the fact that in a calibrated model the seigniorage revenues constitute a small fraction of a country's GDP.

The welfare implications of incomplete fiscal devaluations are reported in the lower panel of Table 2. Even when the fiscal devaluation is imperfect it significantly closes the gap between the no intervention and the full implementation welfare. In the case when only a 
VAT-payroll tax swap is used without any adjustment for capital taxes, the gap is closed by $68 \%$. In the case when the fiscal devaluation is anticipated, it is closed by $79 \%$. In the case when the devaluation is halved in size, from $10 \%$ to $5 \%$, it still covers $53 \%$ of the welfare gap. Finally, the welfare gap between no intervention and a fiscal devaluation (even if imperfect) is both significant and increasing with the degree of wage rigidity (see the online supplement).

In September 2012 Spain raised the standard VAT from 18\% to 21\%, and for several lower tax bracket items (e.g., haircuts, cinema and other entertainment) the tax increases were even bigger. This VAT increase was not accompanied with payroll and capital tax cuts as would be called for in a fiscal devaluation. When we simulate the impact of a $5 \%$ VAT increase alongside the interest rate increase, without any other tax changes, welfare is estimated to decline by more than in the case without any intervention. In the absence of intervention welfare declines by $0.64 \%$. The VAT increase instead reduces it by $0.88 \%$, emphasizing the essential role of a payroll tax cut alongside the VAT increase to capture the benefits of a devaluation.

\section{Conclusion}

In this paper we propose two types of fiscal policies that can robustly implement allocations stemming from a nominal devaluation, but in an economy with a fixed exchange rate. Our proposed fiscal devaluations have a number of appealing features. First, they can be implemented unilaterally by one country using a small set of conventional fiscal instruments. In particular, a one-time unanticipated fiscal devaluation can be implemented adjusting solely the value-added and payroll taxes. Second, they are robust in the sense that they work across a number of economic environments and require virtually no information about the details of the microeconomic environment, in particular about the extent and nature of nominal price and wage rigidity. Third, they are government revenue neutral. Clearly, there are political economy constraints to the size of a feasible fiscal devaluation including tax evasion considerations. Indeed there are limits to how high the VAT can be raised and how much payroll taxes can be cut. An area that we leave for future research is the impact of these factors on implementation. Nevertheless, our results suggest that fiscal devaluations offer a partial but attractive relaxation of Mundell's impossible trinity, allowing for essentially the same outcomes as under an active monetary policy while maintaining a fixed exchange rate and free capital flows. 


\section{Appendix}

\section{A.1 Proof of Proposition 1 (Complete markets)}

Conjecture that $\left\{C_{t}, C_{t}^{*}\right\}$ and the path of relative prices and wages is unchanged. Then from good demand (1), goods-market clearing (9), production functions (8) and labor demand (18), it follows that the rest of the equilibrium allocation is unchanged. In particular consumption and output of individual varieties as well as labor input of individual households are unchanged. We now verify the above conjecture by exploring the equilibrium conditions for price and wage settings, as well as for aggregate consumption.

First, substitute the expression for stochastic discount factor (3) into the wage-setting equation (19). Given the rest of the allocation, the same path of $\left\{\bar{W}_{t}(h)\right\}$ satisfies this condition when

$$
\frac{1+\varsigma_{t}^{c}}{1+\tau_{t}^{n}} \equiv 1 \quad \Leftrightarrow \quad \varsigma_{t}^{c} \equiv \tau_{t}^{n}
$$

Second, consider price setting by home firms for the home market as given by equations (13) under PCP and by (14) under LCP, again after substituting in (3). Given the rest of the allocation, the same path of reset prices $\left\{\bar{P}_{H t}(i)\right\}$ satisfies these conditions when: ${ }^{41}$

$$
\frac{\left(1+\varsigma_{t}^{c}\right)\left(1-\varsigma_{t}^{p}\right)}{1+\tau_{t}^{d}} \equiv \frac{\left(1+\varsigma_{t}^{c}\right)\left(1-\tau_{t}^{v}\right)}{1+\tau_{t}^{d}} \equiv 1
$$

Third, consider international price setting by home firms in the foreign market described by the law of one price (12) under PCP and by equation (15) under LCP respectively. In both cases, $\left\{\bar{P}_{H t}^{*}(i)\right\}$ stays unchanged provided that: ${ }^{42}$

$$
\frac{1}{\mathcal{E}_{t}^{\prime}} \frac{1-\tau_{t}^{v}}{1+\varsigma_{t}^{x}} \equiv \frac{1}{\mathcal{E}_{t}} \quad \Leftrightarrow \quad \frac{1+\varsigma_{t}^{x}}{1-\tau_{t}^{v}} \equiv 1+\delta_{t}
$$

Fourth, consider international price setting by foreign firms in the home market described by the law of one price (16) under PCP and by (17) under LCP. The same path of $\left\{\bar{P}_{F t}(i)\right\}$ satisfies these conditions when

$$
\mathcal{E}_{t}^{\prime} \frac{1+\tau_{t}^{m}}{1-\tau_{t}^{v}} \equiv \mathcal{E}_{t} \quad \Leftrightarrow \quad \frac{1+\tau_{t}^{m}}{1-\tau_{t}^{v}} \equiv 1+\delta_{t}
$$

Now by examining the two fiscal devaluation policies $\left(\mathrm{FD}^{\prime}\right)$ and $\left(\mathrm{FD}^{\prime \prime}\right)$ we conclude that all conditions (A.1)-(A.4) are satisfied in both cases, and therefore (given the conjecture we started

${ }^{41}$ To make the argument more transparent, one can rewrite, for example, the expression for the reset price (13) under PCP as

$$
\bar{P}_{H t}(i)=\frac{\rho}{\rho-1} \frac{\mathbb{E}_{t} \sum_{s \geq t}\left(\beta \theta_{p}\right)^{s-t} C_{s}^{-\sigma} P_{s}^{-1} P_{H s}^{\rho}\left(C_{H s}+C_{H s}^{*}\right)\left[\frac{\left(1+\varsigma_{s}^{c}\right)\left(1-\varsigma_{s}^{p}\right)}{1+\tau_{s}^{d}}\right] \frac{W_{s}}{\alpha A_{s} Z_{s}(i) N_{s}(i)^{\alpha-1}}}{\mathbb{E}_{t} \sum_{s \geq t}\left(\beta \theta_{p}\right)^{s-t} C_{s}^{-\sigma} P_{s}^{-1} P_{H s}^{\rho}\left(C_{H s}+C_{H s}^{*}\right)\left[\frac{\left(1+\varsigma_{s}^{c}\right)\left(1-\tau_{s}^{v}\right)}{1+\tau_{s}^{d}}\right]}
$$

For exact equivalence of reset prices under a fiscal devaluation, the terms in the square brackets in both the numerator and denominator should be identically unity state-by-state and period-by-period, as required by condition (A.2).

${ }^{42}$ This requirement immediately follows from (12) under PCP, but (15) under LCP instead requires

$$
\frac{1+\varsigma_{t}^{c}}{1+\tau_{t}^{d}}\left(1+\varsigma_{t}^{x}\right) \mathcal{E}_{t}^{\prime} \equiv \mathcal{E}_{t} \quad \Leftrightarrow \quad \frac{1+\varsigma_{t}^{c}}{1+\tau_{t}^{d}}\left(1+\varsigma_{t}^{x}\right) \equiv 1+\delta_{t}
$$

However, combining it with (A.2) results in the same condition as under PCP. 
out with) both fiscal devaluations result in the same nominal reset wages and prices as a nominal devaluation. Given motion equations for prices and wage dynamics (e.g., (11)) and the definitions of price indexes (e.g., (2)), this implies that all nominal wages and prices (including price indexes) are mimicked under both fiscal devaluation policies. This, in turn, implies in view of (A.3)-(A.4) that the terms of trade defined in (24) are also mimicked. To additionally mimic the behavior of the real exchange rate in $(26)$, we need to require $\mathcal{E}_{t}^{\prime}\left(1+\varsigma_{t}^{c}\right) \equiv \mathcal{E}_{t}$, which together with (A.1) results in:

$$
\varsigma_{t}^{c} \equiv \tau_{t}^{n} \equiv \delta_{t},
$$

also satisfied by $\left(\mathrm{FD}^{\prime}\right)$ and $\left(\mathrm{FD}^{\prime \prime}\right)$.

We finally verify that the equilibrium values of $\left\{C_{t}, C_{t}^{*}\right\}$ associated with a nominal devaluation are also equilibrium values under our fiscal devaluation policies. Under complete markets, the international risk-sharing condition (25) becomes the familiar Backus-Smith condition (28), where the constant of proportionality $\lambda$ is recovered from the intertemporal budget constraint of the country and stays unchanged across nominal and fiscal devaluations provided that relative prices and terms of trade follow the same path. ${ }^{43}$ As long as we have equivalence in all relative prices, including the real exchange rate, from (28) we obtain equivalence in the relative consumption allocation. The levels of consumption must also be equivalent under nominal and fiscal devaluations to satisfy the aggregate resource constraint (aggregating (9)).

This completes the loop and verifies that the conjecture we started out with is internally consistent. That is, the equilibrium allocations of consumption, labor and output associated with a nominal devaluation and both fiscal devaluations in $\left(\mathrm{FD}^{\prime}\right)$ and $\left(\mathrm{FD}^{\prime \prime}\right)$ coincide.

Finally, under separable utility in money balances, money demand (5) is a side equation, and hence imposes no additional constraints on implementation. ${ }^{44}$ Switching from nominal to fiscal devaluation in general changes the path of the (shadow) nominal interest rate, and hence requires an adjustment in money supply in order to satisfy the altered money demand. The required path of the money supply under a fiscal devaluation policy $\left\{M_{t}^{\prime}\right\}$ can be recovered directly from (5) given the rest of the allocation.

\section{A.2 Fiscal devaluations in financial autarky}

We provide a brief discussion of the case of financial autarky (closed capital account), where the set of risk sharing conditions $(25)$ becomes empty $\left(\Omega_{t} \equiv \emptyset\right)$, and the flow budget constraint (23)

\footnotetext{
${ }^{43}$ Integrating forward the country flow budget constraint (23) using the foreign stochastic discount factor as weights, we arrive at the intertemporal budget constraint of the country

$$
\frac{B_{0}}{P_{0}^{*} \mathcal{E}_{0}}+\mathbb{E}_{0} \sum_{t=0}^{\infty} \beta^{t}\left(\frac{C_{t}^{*}}{C_{0}^{*}}\right)^{-\sigma} \frac{P_{H t}^{*}}{P_{t}^{*}}\left[C_{H t}^{*}-C_{F t} \mathcal{S}_{t}\right]=0
$$

where $B_{0}$ is the home-currency initial net foreign asset position of the home country, and the second term is the sum of all future trade surpluses of the home country discounted by state prices. Note from good demand condition (1) that home and foreign consumption of imports, $C_{F t}$ and $C_{H t}^{*}$, are functions of aggregate consumption $C_{t}$ and $C_{t}^{*}$, as well as relative price $P_{F t} / P_{H t}$ and $P_{F t}^{*} / P_{H t}^{*}$ respectively.

${ }^{44}$ Separability of real money balances in the utility function is a standard assumption in the literature and implies that holdings of real money balances have no affect on the marginal utility of consumption. Hence our equivalence results do not require replicating the equilibrium path of real money balances. If on the other hand we had non-separable utility, equivalence would require the use of an additional tax on money holdings in order to reduce money demand under a fiscal devaluation. This is because expected nominal devaluations result in an increased nominal interest rate and depressed money demand. Replicating an unexpected devaluation, however, does not require an extra instrument even under non-separable utility.
} 
becomes a balanced trade requirement:

$$
C_{H t}^{*}=C_{F t} \mathcal{S}_{t} \quad \Leftrightarrow \quad \frac{C_{t}^{*}}{C_{t}}=\frac{\gamma_{F}}{\gamma_{H}^{*}}\left(\frac{P_{H t}^{*}}{P_{t}^{*}}\right)^{\zeta}\left(\frac{P_{F t}}{P_{t}}\right)^{-\zeta} \mathcal{S}_{t},
$$

where we used demand conditions (1) to substitute in for $C_{H t}^{*}$ and $C_{F t}$. As a result, the real exchange rate plays no role for the allocation as it shows up in no equilibrium condition, and therefore only conditions (A.1)-(A.4) are needed to be satisfied by fiscal devaluation policies. ${ }^{45}$ Note that the reduced fiscal devaluation policies $\left(\mathrm{FD}_{R}^{\prime}\right)$ and $\left(\mathrm{FD}_{R}^{\prime \prime}\right)$ of Proposition 3 satisfy these requirements, but under autarky we need not require that the devaluation is unanticipated.

\section{A.3 Proof of Proposition 3 (Unanticipated devaluations)}

Following the steps of the proof of Proposition 1 (in Appendix A.1), the conditions to mimic the path of wages and prices instead of (A.1)-(A.4) become simply:

$$
\frac{1+\varsigma_{t}^{c}}{1+\tau_{t}^{n}} \equiv 1 \quad \text { and } \quad \frac{1+\varsigma_{t}^{x}}{1-\tau_{t}^{v}} \equiv \frac{1+\tau_{t}^{m}}{1-\tau_{t}^{v}} \equiv 1+\delta_{t}
$$

which are satisfied under both reduced devaluation policies $\left(\mathrm{FD}_{R}^{\prime}\right)$ and $\left(\mathrm{FD}_{R}^{\prime \prime}\right)$. These conditions do not impose a requirement on the use of profit tax $\tau_{t}^{d}$, because under a one-time unexpected devaluation policy it no longer affects price setting in (13)-(15). Indeed, for price setting before $t=0$, no nominal or fiscal policy change is anticipated, so it does not affect price setting; for $t \geq 0$, the change in either nominal or fiscal regime happens once and for all, and hence all taxes can be moved outside the expectation in (13)-(15) and canceled out (also see the expression in footnote 41).

We still need to use profit tax $\tau_{t}^{d}$ if domestic equity is traded internationally in order to replicate the effects on the budget constraint (23) and international risk sharing (25), as shown in Lemma 1. In particular, the path of $D_{t}^{h e *}=\Pi_{t} /\left[\left(1+\tau_{t}^{d}\right) \mathcal{E}_{t}\right]$ must be replicated under a fiscal devaluation, which from the equation for profits (10) requires $\tau_{t}^{d} \equiv \delta$ for $t \geq 0$ under $\left(\mathrm{FD}_{R}^{\prime}\right)$ and $\tau_{t}^{d} \equiv 0$ under $\left(\mathrm{FD}_{R}^{\prime \prime}\right)$. Whenever a home-currency debt is traded, a partial default (haircut) $\tau_{0}^{h}=\delta /(1+\delta)$ is needed in the event (state-period) of a fiscal devaluation in order to replicate the valuation effects in the country budget constraint (23).

Since devaluation is one-time unanticipated, the path of the home nominal risk-free interest rate is unaffected (and in fact, UIP holds in this case as interest parity, $i_{t+1}=i_{t+1}^{*}$, in every period), and therefore money demand in (5) is not affected. As a result, with $\varsigma_{t}^{c}=0$, the same money supply as under a nominal devaluation would also support the fiscal devaluation $\left(M_{t}^{\prime}=M_{t}\right)$, and hence real balances are also unchanged.

Finally, with $\varsigma_{t}^{c}=0$, the path of the real exchange rate is not exactly mimicked relative to a nominal devaluation, however this does not affect the international risk sharing conditions (25). This is because for $t<0$ no policy change is anticipated (zero-probability event), and for $t \geq 0$ the policy change is once and for all, therefore leaving saving and portfolio choice decisions unaffected before, after and at $t=0$. Consequently, the same consumption allocation $\left\{C_{t}, C_{t}^{*}\right\}$ satisfies both the country budget constraint (23) and the international risk sharing conditions (25) under both reduced fiscal devaluation policies $\left(\mathrm{FD}_{R}^{\prime}\right)$ and $\left(\mathrm{FD}_{R}^{\prime \prime}\right)$ as under a nominal devaluation.

\footnotetext{
${ }^{45}$ Note that the domestic Euler equations (4) now become side equations and determine the intertemporal asset prices given the home stochastic discount factor in (3) which need not follow the same path under a nominal and a fiscal devaluation in this case.
} 


\section{A.4 Proof of Proposition 4 (Revenue neutrality)}

Part (i) follows immediately from (30) after substituting in $\epsilon_{t}=\delta_{t}^{m}$ under $\left(\mathrm{FD}^{\prime}\right)$ and $\epsilon_{t}=\delta_{t}^{v}$ under $\left(\mathrm{FD}^{\prime \prime}\right)$. To prove Part (ii), note that under both $\left(\mathrm{FD}_{R}^{\prime}\right)$ and $\left(\mathrm{FD}_{R}^{\prime \prime}\right)$ we can rewrite

$$
P_{t} C_{t}-W_{t} N_{t}=\left(P_{F t} C_{F t}-\left(1+\delta_{t}\right) \mathcal{E}_{0} P_{H t}^{*} C_{H t}^{*}\right)+\left(P_{H t} C_{H t}+\left(1+\delta_{t}\right) \mathcal{E}_{0} P_{H t}^{*} C_{H t}^{*}-W_{t} N_{t}\right),
$$

where the first term is trade deficit $\left(-N X_{t}\right)$ and the second term is profits without taking into account VAT and payroll subsidy (i.e., $\Pi /\left(1-\tau_{t}^{v}\right)$, since $\tau_{t}^{v}=\varsigma_{t}^{p}$ under fiscal devaluations). We can divide and multiple the second term by the dividend tax $\left(1+\tau_{t}^{d}\right)$ to obtain:

$$
P_{t} C_{t}-W_{t} N_{t}=-N X_{t}+\left(1+\delta_{t}\right) \frac{\Pi_{t}}{1+\tau_{t}^{d}},
$$

since under both $\left(\mathrm{FD}_{R}^{\prime}\right)$ and $\left(\mathrm{FD}_{R}^{\prime \prime}\right)$ we have $\left(1+\tau_{t}^{d}\right) /\left(1-\tau_{t}^{v}\right) \equiv 1+\delta_{t}$. Finally, substituting (A.7) this resulting equation into (30), and imposing $\epsilon_{t}=0$ and $\delta_{t}^{m}=\delta_{t}$ or $\delta_{t}^{v}=\delta_{t}$ under the two reduced fiscal devaluations respectively, we obtain (31).

We now prove an additional result that under one-time unanticipated fiscal devaluations the net present value of additional government revenues is non-negative when the stock market capitalization (plus the value of unincorporated business) exceeds the net foreign liabilities of a country:

Lemma A.1 Under $\left(\mathrm{FD}_{R}^{\prime}\right)$ and $\left(\mathrm{FD}_{R}^{\prime \prime}\right)$, the net present value of the additional government revenues equals $\delta$ times the sum of net foreign assets and the capitalization of the business sector of the home country at the time of the devaluation.

Proof: We make use of the budget constraint of the home country (23):

$$
\frac{1}{\mathcal{E}_{t}} \mathbb{E}_{t}\left\{\Theta_{t, t+1} \mathcal{E}_{t+1} \mathcal{B}_{t+1}^{*}\right\}-\mathcal{B}_{t}^{*}=P_{H t}^{*} C_{H t}^{*}-P_{F t} C_{F t} \frac{1}{\mathcal{E}_{t}} \frac{1-\tau_{t}^{v}}{1+\tau_{t}^{m}}
$$

where now $\mathcal{B}_{t}^{*}=\sum_{j \in J_{t-1}}\left(Q_{t}^{j *}+D_{t}^{j *}\right) B_{t}^{j}$ is the foreign-currency equilibrium payoff of the home country international asset portfolio at $t$ (in a given state of the world), or equivalently the foreigncurrency net foreign assets (inclusive of period $t$ returns) of the home country in the beginning of period $t .^{46}$

Using the $N X_{t}$ notation, we can rewrite

$$
\frac{1}{\mathcal{E}_{t}} \mathbb{E}_{t}\left\{\Theta_{t, t+1} \mathcal{E}_{t+1} \mathcal{B}_{t+1}^{*}\right\}-\mathcal{B}_{t}^{*}=\frac{N X_{t}}{\left(1+\delta_{t}\right) \mathcal{E}_{0}},
$$

where we have used the fact that $\mathcal{E}_{t}\left(1+\tau_{t}^{m}\right) /\left(1-\tau_{t}^{v}\right)=\mathcal{E}_{0}\left(1+\delta_{t}\right)$ under both nominal and fiscal devaluations. In the case of a one-time unanticipated devaluation (with $\delta_{t}=\delta$ for $t \geq 0$ ), we solve the above equation forward starting from $t=0$ :

$$
\mathcal{B}_{0}=\mathcal{E}_{0} \mathcal{B}_{0}^{*}=-\sum_{t=0}^{\infty} \mathbb{E}_{0}\left\{\Theta_{0, t} \cdot N X_{t} /(1+\delta)\right\},
$$

where we have imposed the transversality condition for the country international portfolio. Expressing out $N X_{t} /(1+\delta)$ from (31) and substituting it into the intertemporal budget constraint, we obtain

$$
\mathcal{B}_{0}=\sum_{t=0}^{\infty} \mathbb{E}_{0}\left\{\Theta_{0, t} \cdot T R_{t} / \delta\right\}-Q_{0}^{h e}, \quad \text { where } \quad Q_{0}^{h e}=\sum_{t=0}^{\infty} \mathbb{E}_{0}\left\{\Theta_{0, t} \cdot \Pi_{t} /\left(1+\tau_{t}^{d}\right)\right\}
$$

is the (shadow) value of the home business sector (stock market capitalization plus the value of unincorporated businesses). Combining and multiplying through by $\delta$ results in

$$
\sum_{t=0}^{\infty} \mathbb{E}_{0}\left\{\Theta_{0, t} T R_{t}\right\}=\delta \cdot\left(\mathcal{B}_{0}+Q_{0}^{h e}\right)
$$

\footnotetext{
${ }^{46}$ Note that $\frac{1}{\mathcal{E}_{t}} \mathbb{E}_{t}\left\{\Theta_{t, t+1} \mathcal{E}_{t+1} \mathcal{B}_{t+1}^{*}\right\}=\mathbb{E}_{t}\left\{\Theta_{t, t+1}^{*} \mathcal{B}_{t+1}^{*}\right\}$ is the period $t$ foreign-currency value of holding a state-contingent net foreign asset position $\mathcal{B}_{t+1}^{*}$ in period $t+1$, where the equality holds in view of the risk sharing conditions (25).
} 


\section{References}

Adao, B., I. Correia, And P. Teles (2009): "On the relevance of exchange rate regimes for stabilization policy," Journal of Economic Theory, 144(4), 1468-1488.

Andrade, P., M. Carré, and A. Bénassy-Quéré (2010): "Competition and pass-through on international markets: Firm-level evidence from VAT shocks," CEPII.

Atkeson, A., And A. Burstein (2008): "Pricing-to-Market, Trade Costs, and International Relative Prices," American Economic Review, 98(5), 1998-2031.

Benigno, G., P. Benigno, and F. Ghironi (2007): "Interest rate rules for fixed exchange rate regimes," Journal of Economic Dynamics and Control, 31(7), 2196-2211.

Benigno, G., And H. Kucuk-Tuger (2012): "Portfolio allocation and International Risk Sharing," Canadian Journal of Economics, 45(2), 535-565.

Berglas, E. (1974): "Devaluation, Monetary Policy, and Border Tax Adjustment," Canadian Journal of Economics, 7(1), 1-11.

Boscam, J. E., A. Diaz, R. Domenech, J. Ferri, E. Perez, and L. Puch (2011): "Rems: A Rational Expectations Model for Simulation and Policy Evaluation of the Spanish Economy," in The Spanish Economy: A General Equilibrium Perspective, ed. by J. Bosca, R. Domenech, J. Ferri, and J. Varela. Palgrave Macmillan.

Broda, C., And D. Weinstein (2006): "Globalization and the Gains from Variety," Quarterly Journal of Economics.

Calmfors, L. (1998): "Macroeconomic Policy, Wage Setting and Employment-What difference does the EMU make?," Oxford Review of Economic Policy, 14(3), 125-151.

Campa, J. M., L. S. Goldberg, and J. M. GonzÁlez-Mínguez (2005): "Exchange-Rate PassThrough to Import Prices in the Euro Area," NBER Working Papers No. 11632.

Carare, A., And S. Danninger (2008): "Inflation Smoothing and the Modest Effect of VAT in Germany," IMF Working Papers No. 08/175.

Carbonnier, C. (2007): "Who pays sales taxes? Evidence from French VAT reforms, 1987-1999," Journal of Public Economics, 91(5-6), 1219-1229.

Cavallo, D., And J. CotTani (2010): "For Greece, a "Fiscal Devaluation" is a Better Solution than a "Temporary Holiday" from the Eurozone," VoxEU, http://www.voxeu.org/article/ greece-should-try-fiscal-devaluation-not-holiday-eurozone.

Christiano, L., M. Eichenbaum, and S. Rebelo (2011): "When Is the Government Spending Multiplier Large?," Journal of Political Economy, 119(1), 78 - 121.

Correia, I., E. Farhi, J. P. Nicolini, And P. Teles (2011): "Unconventional Fiscal Policy at the Zero Bound," NBER Working Papers No. 16758.

Correia, I., J. P. Nicolini, And P. Teles (2008): "Optimal Fiscal and Monetary Policy: Equivalence Results," Journal of Political Economy, 116(1), 141-170.

Corsetti, G. (2008): "New Open Economy Macroeconomics," in The New Palgrave Dictionary of Economics, ed. by S. N. Durlauf, and L. E. Blume. Palgrave Macmillan, Basingstoke.

Devereux, M. B., And A. Sutherland (2008): "Country Portfolios in Open Economy Macro Models," NBER Working Papers No. 14372.

Eggertsson, G. (2004): "Comment on How Do Monetary and Fiscal Policy Interact in the European Monetary Union?," NBER International Seminar on Macroeconomics, pp. 241-325. 
European Commission (2011): Taxation trends in the European Union. European Commission.

FArhi, E., ANd I. Werning (2007): "Quelques Considérations sur la Mise en Place de la "TVA Sociale" en France," http://web.mit.edu/iwerning/Public/VAT.pdf.

Feenstra, R., M. Obstfeld, And K. Russ (2010): "In Search of the Armington Elasticity," Working Paper.

Feenstra, R. C. (1985): "Anticipated Devaluations, Currency Flight, and Direct Trade Controls in a Monetary Economy," American Economic Review, 75(3), 386-401.

Feldstein, M. S., And P. R. Krugman (1990): "International Trade Effects of Value-Added Taxation," in Taxation in the Global Economy, NBER Chapters, pp. 263-282. National Bureau of Economic Research, Inc.

FrAnco, F. (2011): "Improving competitiveness through fiscal devaluation, the case of Portugal," Universidade Nova de Lisboa.

Galí, J. (2008): Monetary Policy, Inflation and the Business Cycle: An Introduction to the New Keynesian Framework. Princeton University Press.

Gourinchas, P.-O., And H. Rey (2007): "From World Banker to World Venture Capitalist: U.S. External Adjustment and the Exorbitant Privilege," in G7 Current Account Imbalances: Sustainability and Adjustment, NBER Chapters, pp. 11-66. National Bureau of Economic Research, Inc.

Grossman, G. M. (1980): "Border tax adjustments: Do they distort trade?," Journal of International Economics, 10(1), 117-128.

IMF (2011): Fiscal Monitor: Addressing Fiscal Challenges to Reduce Economic Risks. International Monetary Fund.

Kimball, M. (1995): "The Quantitative Analytics of the Basic Neomonetarist Model," Journal of Money, Credit and Banking, 27, 1241-77.

LANE, P. R. (2001): "The new open economy macroeconomics: a survey," Journal of International Economics, 54(2), 235-266.

Lipińska, A., And L. Von Thadden (2009): "Monetart and Fiscal Policy Aspects of Indirect Tax Changes in a Monetaty Union," ECB Working Papers No. 1097.

LucAs, R. (1987): Models of Business Cycles. Basil Blackwell, Oxford.

Neumeyer, P. A., And F. Perri (2005): "Business cycles in emerging economies: the role of interest rates," Journal of Monetary Economics, 52(2), 345-380.

Obstfeld, M., And K. Rogoff (2000): "New Directions for Stochastic Open Economy Models," Journal of International Economics, 50, 117-153.

Poterba, J. M., J. J. Rotemberg, and L. H. Summers (1986): "A Tax-Based Test for Nominal Rigidities," American Economic Review, 76(4), 659-75.

Schmitt-Grohé, S., And M. Uribe (2011): "Pegs and Pain," Columbia Univeristy.

Silva, S. J., And S. Tenreyro (2010): "Currency Unions in Prospect and Retrospect," Annual Review of Economics, 2, 51-74.

Staiger, R. W., And A. O. Sykes (2010): "Currency manipulation' and world trade," World Trade Review, 9(4), 583-627.

Woodford, M. (2003): Interest and Prices: Foundations of a Theory of Monetary Policy. Princeton University Press. 